\title{
ChILE A MÁs DE DOS DÉCADAS DE JUSTICIA DE TRANSICIÓN
}

Cath Collins (c.collins@ulster.ac.uk)

Universidad Diego Portales, Chile

Universidad de Ulster, Irlanda del Norte

Este trabajo examina las principales políticas públicas y medidas oficiales en materia de justicia de transición -verdad, justicia, reparaciones y garantías de no repetición- logrados en Chile desde 1990 con respecto a violaciones masivas de los Derecho Humanos cometidas bajo la dictadura cívico-militar de 1973 a 1990. Concluye que el balance actual de avances graduales y aún parciales ha sido el resultado de presiones desde la sociedad civil e inesperadas 'irrupciones de la memoria', más que de una política oficial sistemática de repudio a la violencia política y atención al manejo de su legado.

Palabras clave: Violaciones de derechos humanos, verdad, justicia, reparaciones.

\section{CHILE: MORE THAN TWO DECADES OF TRANSITIONAL JUSTICE}

This paper examines the principal transitional justice measures - concerning finding out the truth, justice, compensation and the guarantees of nonrepetition- implemented in Chile since 1990 concerning the massive human rights violations that occurred during the civilian-military dictatorship from 1973 to 1990. It concludes that the gradual and, as yet, still partial advances made have been the result of pressure from a minority of civilians, as well as unanticipated 'memory irruptions', rather than as a result of a consistent or systematic state policy of repudiation and addressing of the legacies of recent political violence.

Keywords: Human Rights Violations, truth, justice, reparations. 


\section{Introducción: el 'caso chileno' a grandes rasgos}

El caso chileno suele ser considerado como uno de los 'casos clásicos' de la fase moderna de justicia de transición, entendida como la realización de esfuerzos para manejar el legado de violaciones masivas a los DD.HH. a través de medidas en las áreas de verdad, justicia, reparaciones y garantías de no-repetición ${ }^{1}$. La adopción, utilidad e impacto de dichas medidas suelen estar íntimamente relacionados, en un primer momento, con el tipo de transición política que se ha producido y con la correlación de fuerzas políticas que aquella produce. También está claro en la actualidad que los procesos de transición, y el legado de violencia política, se prolongan en el tiempo, haciéndose presente de modo cíclico pero ineludible en la vida nacional a través de 'irrupciones de memoria' (Wilde, 1999).

El caso de Chile no es la excepción. En el año 2013, fecha del cuadragésimo aniversario del golpe de Estado que dio origen a las violaciones, ya ha quedado claro que el legado de estas cuatro décadas está absolutamente vigente en la agenda pública y la vida nacional. En agosto de 2013, un ex comandante en jefe del Ejército debió renunciar a su puesto de dirección en el servicio electoral luego de que volvieran a surgir cuestionamientos sobre su conexión con un caso de ejecución extrajudicial que había dejado huérfano a un niño de dos años ${ }^{2}$. En las elecciones presidenciales de fin de año, la hija de un general de la Fuerza Aérea, muerto a manos de sus propios compañeros por su constitucionalismo y oposición al golpe, se enfrentó como candidata con la hija de otro general de la misma fuerza, fiel hombre del régimen y alguna vez integrante de la junta militar.

Como si esto fuera poco, el segundo, Fernando Matthei, ha sido acusado en forma reiterada de tener responsabilidad penal o moral en la muerte del primero, Alberto Bachelet. Todo aquello tomó lugar bajo un gobierno de derecha, el primero en los cinco periodos presidenciales de la pos-transición, y con el trasfondo de una ahora activa, si bien aún parcial, apertura a la justicia formal en la forma de la persecución penal de los responsables de algunos de los crímenes estatales más aberrantes cometidos

Ver mandato y primer informe anual del nuevo Relator Especial de la ONU para la Promoción de la Verdad, la Justicia, las Reparaciones y las Garantías de No-Repetición: respectivamente, Resolución 18/7 del Consejo de DDHH de la ONU y documento ONU A/HC/21/46, agosto de 2012.

2 El niño, ahora un hombre de 42 años, se enfrentó con el ex general Juan Emilio Cheyre en un programa de televisión. Dejó en claro que no creía la postura de Cheyre de que ni él ni la institución que había dirigido entre 2002 y 2006 manejaban más información sobre éste ni sobre otros casos, y le emplazó a colaborar para esclarecer el paradero de las más de mil personas aún detenidas desparecidas en Chile. 
entre 1973 y 1990. Este paper explora brevemente las características del terrorismo de Estado que dio origen a los principales desafios para Chile en materia de justicia de transición, para luego describir y evaluar lo sucedido en dos periodos: 1990-1998, y 1998 hasta la actualidad. Se enfoca en la dimensión de la justicia formal (justicia en tribunales), siendo ésta la dimensión en que se han producido mayores cambios, si bien se considera además las dimensiones de verdad y reparaciones, y se comenta los principales hitos en la incipiente construcción de una arquitectura institucional de defensa y promoción de los derechos humanos que, de consolidarse, constituirá sin duda un aporte a la no-repetición. Saca un balance que sugiere que lo realizado hasta la fecha a nivel de actuar oficial es significativo, si quizás inevitablemente, insuficiente comparado a la magnitud del daño ocasionado. Además parece haber sido, en Chile como en otras latitudes, producto tanto o más de una persistente lucha minoritaria de activistas y actores de la sociedad civil que de una decisión estatal de encabezar un inequívoco y enérgetico repudio de las peores manifestaciones del autoritarismo político. ${ }^{3}$

\section{La naturaleza y el balance del terrorismo de Estado en Chile}

Formando parte de la así llamada 'tercera ola' de transiciones desde autoritarismo a democracia en el Cono Sur de América en los 1980 y 1990, Chile emergió a fines de los 1980 de un régimen cívico-militar autoritario de derecha, impuesto tras un violento golpe de Estado encabezado en 1973 por el entonces comandante en jefe del Ejército, Augusto Pinochet. El régimen se había dedicado a revertir y a erradicar, a través de técnicas concertadas de terrorismo de Estado, el pensamiento y actuación política de izquierda que había alcanzado su máxima expresión en el gobierno de la Unidad Popular (1970-1973) encabezado por el socialista Salvador Allende. Allende murió el mismo día del golpe de Estado, en las ruinas del bombardeado palacio de gobierno. En los días y meses siguientes, su gabinete, autoridades locales, dirigentes de partidos políticos, de sindicatos o de movimientos sociales fueron perseguidos y luego apresados, exiliados, torturados, ejecutados o desaparecidos por servicios de seguridad regulares y clandestinos. Los derechos civiles y políticos fueron suspendidos y la libertad de prensa y de reunión truncada. Se dio inicio a

Observación que no pretende invisibilizar la preocupación constante de quienes, emergiendo de la importante comunidad de defensa de los DD.HH. que surgió en Chile durante la dictadura, han hecho serios e importantes esfuerzos 'desde dentro' para persuadir a los gobiernos de la Concertación, en particular, de la necesidad de adoptar iniciativas más robustas, sino que refleja la limitada aceptación y priorización de sus recomendaciones y consejos por parte de dichas autoridades. 
una cadena de decretos de estados de sitio o de emergencia que serían renovados en forma casi continua durante los 17 años que perduró el régimen.

La represión rápidamente amplió su terreno de actuación más allá de los partidos políticos que habían sido su blanco inicial, apuntando también a líderes estudiantiles, artistas, músicos, dirigentes sindicales y populares y otros actuales o presuntos simpatizantes de la izquierda política. Las cifras oficiales actuales certifican 3.216 personas muertas o desaparecidas, y otras 38.254 apresadas por razones políticas y/o torturadas, en el período ${ }^{4}$. La temprana formación de organizaciones de defensa y denuncia dentro y fuera del país, fomentada en parte por un éxodo de refugiados y exiliados altamente capacitados y con experiencia política, ayudó a posicionar a Chile como cause célèbre para la incipiente comunidad internacional de defensa de los derechos humanos. No obstante, el régimen defendió su deteriorada imagen internacional acusando, ante cada denuncia o resolución condenatoria en las Naciones Unidas, incomprensión, mala fe o derechamente una conspiración marxista internacional en su contra. En 1977 moderó por lo menos superficialmente su entusiasta práctica represiva, producto en parte de presión directa recibida por los EEUU luego de haber asesinado a un connotado exiliado en el corazón de la capital misma. ${ }^{5}$ Disolvió la ya notoria DINA, cuerpo de policía política que reportaba directamente de Pinochet, e introdujo una ley de amnistía como si fuera para señalar su intención de dar vuelta a la página e inaugurar una nueva era. La ley en cuestión, el Decreto Ley 2.191 de 1978, fue en esencia una auto-amnistía, diseñada para favorecer a agentes de los servicios de seguridad. ${ }^{6}$ Si bien el nuevo servicio de inteligencia, el CNI, mataba menos, seguía matando, ejerciendo fuertemente

4 Cifras acumulativas a agosto 2011, fecha en que se declaró el cierre oficial definitivo de calificaciones individuales realizadas por el Estado chileno en cinco etapas desde 1991. Cifras compiladas por el Observatorio DDHH de la Universidad Diego Portales desde fuentes oficiales. Ver www.icso.cl/ observatorio-derechos-humanos , sección Publicaciones, documento 'Cifras de Víctimas'.

$5 \quad$ El asesinato por coche-bomba de Orlando Letelier, ex canciller chileno, y una colega estadounidense en pleno barrio diplomático de Washington DC en 1976, representa quizás uno de los peores errores de cálculo excesos de soberbia de la DINA. Su incursión en territorio estadounidense provocó el vigoroso rechazo incluso de simpatizantes de la dictadura chilena dentro del Departamento de Estado de EEUU.

6 La ley otorga amnistía a quien haya cometido delitos entre septiembre 1973 y abril de 1978 -fecha de su introducción- pero excluye a quienes ya habían sido, o estaban siendo, procesados por tribunales. Como las únicas personas procesadas por delitos de motivación política antes de 1990 eran opositores -y muchos de ellos por cargos falsos-, la claúsula sirvió como manera de excluir a la oposición del alcance de la amnistía hasta iniciada la transición política. A partir de 1990, sí fue invocada para conmutar sentencias en algunos casos de opositores condenados por crímenes violentos, si bien la Corte Interamericana de DDHH no tuvo dudas de caratularla en 2006 como una auto-amnistía (Corte Interamericana, Sentencia de 26 de septiembre de 2006, Almonacid y otros vs. Chile). 
su vocación represiva hasta los últimos días del régimen. Blindado como muchos de sus pares de la época por el anticomunismo y la doctrina de seguridad nacional entonces imperantes en el Occidente, el régimen chileno buscó además legitimarse a través de la adopción de un experimento más o menos neoliberal, acorde con el zeitgeist, y cuyos resultados revindicó como un "milagro económico'7.

La combinación de radicales transformaciones económicas con institucionalización política y contención autoritaria de los costos sociales permitió al régimen no solamente sobrevivir sino hacer proyecciones. Siguiendo un calendario establecido por la misma dictadura en una nueva constitución política impuesta en 1980, se celebró en 1988 un plebiscito para determinar si Pinochet debiera seguir en el poder. Aunque el régimen perdió el plebiscito, fue por un margen relativamente estrecho. Por tanto, las elecciones que procedía celebrar en 1989 ofrecían de todos modos una posibilidad real de un resultado que diera continuidad al régimen, si bien éste, a insistencia ya del empresariado, la derecha civil, y algunas corrientes dentro de las mismas fuerzas armadas, ofreció un candidato civil en vez del mismo Pinochet u otro militar. Con aquellas elecciones, las primeras celebradas en casi dos décadas, el país retomó una tradición de democracia constitucional relativamente estable, si bien nunca exenta históricamente de prácticas anti-populares y a veces abiertamente represivas. ${ }^{8}$ En los inicios de la recuperación de la democracia electoral, una coalición de centro-izquierda, compuesta de 17 partidos y conocida como la 'Concertación', ganó la presidencia en la persona del demócrata cristiano, DC, Patricio Aylwin (1990-1994), y seguiría en ello durante 3 períodos presidenciales consecutivos más (hasta que el candidato DC y otrora presidente Eduardo Frei Ruiz-Tagle perdiera ante el candidato de derecha Sebastián Piñera a fines del 2009).

\section{La transición tutelada}

No obstante sus dos décadas de continuidad en la presidencia, la Concertación tuvo que contar siempre con una oposición política fuerte, compuesta de un partido de derecha tradicional (RN), y otro fundado durante la dictadura (UDI). Éstos abogaron para preservar las principales líneas del régimen anterior, demostrando abierta simpatía y consonancia con él e incluyendo en sus filas personajes que

Tanto la ortodoxia del modelo económico como sus resultados macroeconómicos han sido cuestionados por, entre otros, Huneeus (2011), Angell (2006 y 2013), Muñoz (2007).

8 Ver los importantes trabajos recientes de Elizabeth Lira y Brian Loveman, quienes demuestran que el 'mito' del excepcionalismo chileno en cuanto a tendencias autoritarias, y/o al uso de amnistías y olvido para borrar episodios de violencia estatal es, justamente, un mito. 
habían servido en altos puestos en él. De este modo, se dieron grandes cuotas de continuidad dentro de un contexto de aparente reemplazo político, ya que la derecha mantuvo siempre una alta representación legislativa y electoral hasta retomar la presidencia en 2010. Fue meticulosa en defender la conversión neoliberal de la economía realizada en los años de dictadura, y se opuso tajantemente a cualquier esfuerzo para reformar las líneas principales de la Constitución de 1980 -que fue preservada- o para promover accountability judicial o una condena moral inequívoca a los crímenes cometidos por el régimen anterior. Éstos fueron reconocidos en un primer momento, a través de una Comisión de la Verdad, pero en el ámbito de la justicia seguían siendo sujetos a amnistía. En la medida que avanzaba la transición, las violaciones masivas a los derechos humanos cometidas en tiempos de dictadura seguían siendo abiertamente negadas o justificadas por algunos, y empezaron a ser pasadas por alto o consignadas a un segundo plano por otros. El tema empezó a ser dejado de lado a favor de una agenda nacional más consensuada, o por lo menos más propicia para intervenciones fructuosas, dadas las condiciones políticas imperantes. La centro-izquierda gobernante enfatizó la necesidad de administrar con responsabilidad el modelo heredado, para posibilitar cierto nivel de atención a la urgente 'deuda social'. Una necesaria convivencia con Pinochet, constitucionalmente protegido hasta por lo menos 1998 en su antiguo puesto de comandante en jefe del ejército, impuso una lógica de tolerancia de continuidad en el alto mando de las fuerzas armadas, así como en la Corte Suprema y otros reductos colonizados por el General en sus casi dos décadas al mando del país.

Los acuerdos y el consenso fueron la orden del día,independientemente de si se tratase de la administración pública, el sistema de justicia, los privilegios militares, el modelo de crecimiento económico o el andamio político en general. Tanto aquí como en el ámbito específico de políticas públicas de verdad,justicia, reparación y memoria por los crímenes de Estado cometidos bajo el régimen saliente, la trayectoria transicional del Chile concertacionista tiene dos posibles, pero contradictorias, caracterizaciones. Según la primera de ellas, puede ser leída como un ejemplo de las virtudes de la paciencia y el incrementalismo. El gobierno democrático entrante enfatizó la estabilidad, operando dentro de los parámetros del sistema heredado y realizando modificaciones graduales sin revertir las principales transformaciones realizadas por el régimen anterior. Por otra parte, puede ser leída como un caso de excesiva cautela, demora o deferencia a sensibilidades autoritarias, ya que el gobierno de centroizquierda fue eventualmente derrotado en las urnas con importantes metas aún sin cumplir. Pocos de los repentinos avances en justicia de transición, vividos en la segunda década de la transición chilena podrían ser atribuidos al actuar decidido de 
la Concertación. De hecho, algunos de esos mismos avances parecían derechamente impulsados por la frustración y decepción que su tibieza provocó en quienes habían esperado un actuar más robusto en repudio al régimen autoritario y sus crímenes.

\section{¿Too little, too late? Justicia de transición como empresa oficial}

La trayectoria inicial de Chile en cuanto a políticas públicas de verdad, justicia y reparaciones aplicadas al legado de violaciones masivas a los DD.HH. cometidas en los 17 años de dictadura fue claramente marcada por las características de su transición 'pactada' - en realidad, un cambio de régimen mucho más impuesto que negociado. En ella, los poderes fácticos salientes buscaron, y obtuvieron, continuidad y 'garantías de salida' en los ámbitos político-institucionales, económicos, militares y de justicia. Pinochet mismo se jactaba de haber dejado al país 'atado, y bien atado', con disposiciones conocidas como 'leyes de amarre' asegurando la continuidad de sus partidarios, y por supuesto de su misma persona, en puestos claves de poder. Si bien entre plebiscito y elecciones se lograron negociar algunas modificaciones constitucionales - una de las cuales, relevante para el proceso de reconocimiento interno del derecho internacional, llegaría a ser clave muchos años después- en términos generales se seguía conviviendo con la Constitución, el Senado y modelo económico que el régimen saliente había diseñado. La derecha contaba cpn alta represenación en ambas cámaras, y en el poder judicial reinaba la continuidad. .El balance inicial de accountability fue, en consecuencia, bastante mínimo considerando de qué se trataba: el remplazo de un régimen internacionalmente notorio por flagrantes abusos por una oposición fuertemente asociada con un discurso de derechos humanos, y en cuyas filas figuraban muchas víctimas directas o indirectas de represión.

Pero en los hechos, los primeros años del retorno a la democracia en Chile vieron algo de verdad, en la forma de una comisión, muy poco de justicia, y algo de reparaciones. El decreto ley de amnistía de 1978 fue dejado absolutamente intacto, revirtiendo casi de inmediato una promesa de campaña de anulación. El tono fue en general conciliatorio con las FFAA salientes, quienes llegaron incluso a amenazar abiertamente a la naciente institucionalidad democrática con levantamientos militares, motivados que incluían el legado no resuelto de violaciones a los DD.HH. ${ }^{9}$ El sector

\footnotetext{
Ante indicios de posibles investigaciones o presiones para resolver crímenes de Estado y el involucramiento de uno de los hijos de Pinochet, hubo dos incidentes graves durante la primera administración democrática, presidida por el presidente Patricio Aylwin (1990-1994). En uno de ellos, tropas en uniforme de guerra circulaban por las calles de la capital en 'ejercicios' militares claramente motivados por el deseo de sembrar temor en la población.
} 
popular del movimiento defensor de los DD.HH., hasta entonces un importante componente de la campaña nacional e internacional que había logrado desacreditar la dictadura y prevalecer en el plebiscito de 1988, fue en gran parte marginado de los centros de poder bajo el nuevo gobierno. Sus exigencias maximalistas fueron consideradas imposibles de satisfacer dadas las condiciones políticas prevalecientes; el apoyo externo que había recibido de comités de solidaridad empezó a desaparecer; y el liderazgo de la Iglesia Católica, que había sido muy importante en tiempos de dictadura, se perdió. La Iglesia institucional se retiró formalmente del campo de promoción y defensa de los DD.HH., llegando a lo largo de los 1990 a dedicarse más bien a una agenda moral de tinte más conservadora ${ }^{10}$.

Estos cambios de énfasis y de agenda no quieren decir que el primer gobierno democrático haya sido totalmente insensibles a los crímenes de represión y sus consecuencias. A las vivencias personales se sumaron las vivencias políticas de las nuevas autoridades: muchos de los partidos miembros de la coalición ahora gobernante habían visto sus filas diezmadas de modo sistemático por agentes de los servicios de inteligencia durante los 1970 y $1980 .{ }^{11}$ El propio primer presidente concertacionista Patricio Aylwin, estuvo íntimamente conectado a las consecuencias humanas de estas pérdidas a través de su hermano Andrés, un abogado quien durante la dictadura había trabajado incansablemente en la defensa y socorro de víctimas del régimen y de sus familiares. A recomendación de un comité de profesionales encargados de hacer una propuesta en DD.HH. para el nuevo gobierno, se creó entonces la Comisión Nacional de Verdad y Reconciliación, conocida como

10 Se cerró, por ejemplo, la Vicaría de la Solidaridad, emblemático paraguas de esfuerzos de protección legal y social a víctimas, familiares y sobrevivientes de represión. La agenda moral inmpliacaba oponerse a la introducción de una ley de divorcio, al reconocimiento de uniones de parejas del mismo sexo, y a ciertas medidas en derechos reproductivos tales como la legalización de la píldora del día después. La Iglesia institucional se veía de este modo cada vez más alejada de, o incluso enfrentada con, el gobierno concertacionista; particularmente en sus dos últimos períodos consecutivos, cuando fue presidido por candidatos socialistas sin particular cercanía al catolicismo (Ricardo Lagos, 20002006, y Michelle Bachelet, 2006-2010).

11 Particularmente afectados fueron el Partido Socialista -integrante de la coalición- y el Partido Comunista y el Movimiento de la Izquierda Revolucionaria, MIR. Estas dos últimas colectividades optaron por mantenerse al margen de la Concertación. Una vez iniciada la democracia, operaron como oposición desde la izquierda de la coalición gobernante. De los dos, solamente el Partido Comunista se reconstituyó como partido registrado. El ala centrista de la Concertación, el Partido Demócrata Cristiano (PDC), incluía quienes habían criticado duramente al gobierno de Allende, e incluso algunas personas que habían dado su apoyo inicial al golpe. No obstante, también fue el partido de afiliación de varios de los personajes más conocidos en la defensa de los DD.HH. 
'Comisión Rettig'. La comisión, operando bajo mandato presidencial, ${ }^{12}$ recibió testimonios, estudió documentación y se adentró en los archivos de las múltiples organizaciones de defensa de los DD.HH. que habían operado durante la dictadura. ${ }^{13}$ Reporteó en 1991, y dado el contexto político imperante su informe final fue en efecto una comprensiva y valiente exposición de la sistematicidad de la criminalidad del régimen. Documentó centenares de centros clandestinos de detención y tortura, analizó las estructuras y modus operandi de los servicios de inteligencia regulares e irregulares del régimen, y calificó algo más de dos millares de víctimas directas, individualizadas en una nómina alfabética señalando los datos biográficos y circunstancias de la muerte o desaparición de cada persona. La composición políticamente 'equilibrada' de la Comisión, que incluía igual número de personas asociadas con la derecha y con la centro-izquierda del espectro político, dio peso a sus consideraciones y conclusiones -si bien las FFAA y el poder judicial del momento de todos modos rechazaron en forma enérgica las críticas formuladas a su actuar.

Sin duda un paso significativo en el reconocimiento y difusión de la verdad sobre los crímenes represivos cometidos entre 1973 y 1990, la Comisión resultó ser la principal sino la única iniciativa importante de la época. Planes para una mayor difusión oficial de sus conclusiones, en la forma de una 'caravana' nacional que recorrería las regiones de Chile, fueron abortados a solo días de la publicación oficial. El asesinato de Jaime Guzmán, un prominente político de la derecha, provocó temor en las filas oficialistas ante un posible resurgimiento de violencia política. ${ }^{14}$ Por tanto, el principal efecto práctico inmediato de la comisión Rettig fue el haber estimulado el otorgamiento de medidas de reparación. Un programa de acceso a salud pública para sobrevivientes, familiares y algunos defensores de derechos humanos fue complementado por el otorgamiento de pensiones económicas al núcleo familiar

12 Lo cual le privaba de poderes de requisar documentos, requerir comparecencia de ex autoridades, etc. Dichos poderes habrían requerido una comisión con mandato legislativo, algo que la comunidad de DD.HH. quería pero el gobierno estimó imposible de lograr.

13 Entre ellos, la Vicaría de la Solidaridad de la Iglesia Católica, quizás la más grande y mejor equipada; la Fundación de Ayuda Social de las Iglesias Cristianas, FASIC; el Comité de Defensa de los Derechos del Pueblo, CODEPU; la Comisión Chilena de los DD.HH, y un sinfín de organizaciones de base, comunitarias, y locales dispersos a lo largo del territorio.

14 Guzmán, otrora colaborador cercano de Pinochet y recién electo senador, fue acribillado por un comando de un grupo de la izquierda armada a la salida del campus de la Universidad Católica, donde ejercía docencia en la Escuela de Derecho. Uno de los fundadores en los 1980 del partido pinochetista Unión Demócrata Independiente, UDI, Guzmán fue un importante asesor político y económico del régimen, asociado con los 'Chicago Boys' quienes implementaron el modelo económico neoliberal que la dictadura adoptó. Suele ser considerado como uno de los principales autores de la Constitución de 1980 y su modelo de 'democracia tutelada' (restringida o limitada). 
de personas nombradas en el informe Rettig como ejecutadas o desaparecidas. ${ }^{15} \mathrm{Un}$ monumento público a esas mismas víctimas fue legislado (si bien su realización y entrega demoró varios años más), y se dio cierta continuidad a la misma Comisión con la creación de un ente sucesor encargado de seguir calificando casos así como de intentar esclarecer el destino final y/o ubicar los restos de quienes seguían desaparecidos ${ }^{16}$. Pero se desechó, sea por accidente o por diseño, la oportunidad de armar una institucionalidad permanente y más completa en DD.HH., una que no solamente se haría cargo más ampliamente de la verdad, justicia y memoria respecto al pasado sino también asumiría un rol de promoción y vigilancia a futuro ${ }^{17}$.

Más bien, luego de esas iniciativas tempranas en verdad y reparaciones, sobrevino un tiempo de aparente quietud. Las reivindicaciones de familiares y sobrevivientes despertaron poco eco en las autoridades o en la sociedad en general, mientras que los militares y otros participantes y beneficiarios de la dictadura mantuvieron, en buena medida, tanto sus privilegios económicos como su impunidad frente a la justicia. Tampoco se vivía un aire de repudio o condena social generalizado hacia el régimen militar y sus prácticas, incluso las más repugnantes: el régimen, así como la derecha política que decía ser su heredera, mantuvieron altos índices de apoyo y aprobación. ${ }^{18}$ En este contexto, luego de la primera Comisión de la Verdad y reparaciones conexas en 1991, 1992, y 1996, hubo poca innovación o cambio hasta que el año 1998, fecha que, en forma sorpresiva, se transformó en un importante punto de inflexión. Dio paso a una primera apertura en justicia, complementada y nutrida por reaperturas de los temas de verdad, reparación y memoria. De ello se desprenderían, a lo largo de la década subsiguiente, centenares de casos judiciales, una nueva comisión de la verdad, la ampliación de medidas de reparación y la

15 Hubo una serie de otras medidas menores, incluyendo programas para fomentar el retorno de exiliados y de restituir derechos previsionales a quienes habían sido despedidos de su trabajo por motivos políticos (este última categoría llegando a ser conocida en Chile como 'exonerados políticos'). Para detalles, ver tabla 1 (medidas de reparación) y www.icso.cl/observatorio-derechoshumanos , sección Publicaciones, subsección Reparaciones, documentos 'Leyes y Medidas de Reparación' y 'Tabla de Medidas'.

16 La Comisión Nacional de Reparación y Reconciliación, CNRR, y su Informe, publicado en 1996.

17 La misma instancia de continuidad advirtió este deficit al señalar, en su informe de 1996, tareas pendientes en DD.HH.

18 Debido en parte al sistema electoral binominal, y a la concesión de escaños senatoriales no-electos a ciertas autoridades una vez jubiladas, la derecha mantuvo siempre la capacidad en las dos cámaras legislativas de bloquear o modificar proyectos del gobierno. Dicho poder se hizo aun más notorio tratándose de modificaciones constitucionales, ya que éstas generalmente requerían 'supermayorias' fuera del alcance de la coalición gobernante. 
recuperación y rehabilitación de una docena de sitios clandestinos de represión y tortura para servir como lugares de defensa y promoción de los DD.HH.

Esta reapertura significativa no fue el resultado de protagonismo oficial, sino más bien de una confluencia de presiones desde actores no estatales, domésticos y externos, con cambios contextuales afectando la receptividad en el sistema de justicia. Estos cambios, y sus consecuencias en materia de verdad, memoria, pero particularmente en justicia, serán el enfoque principal del resto de este texto.

\section{Justicia de transición en Chile, fase 1, 1990-1998: "aquí no pasó nada"}

Roberto Garretón, destacado abogado defensor de los DD.HH. del período, suele remarcar, con el brío y la agudeza que lo caracterizan, lo estático que fue el escenario de justicia de transición durante buena parte de la primera década concertacionista. La postura prevaleciente, entre implicados directos o espectadores casi por igual, fue, según él, la del avestruz. Se negó a reconocer las reales dimensiones, o incluso la existencia misma, de un problema vivo y actual relacionado con la continua falta de justicia. Si bien se subscribían tratados internacionales, y se expandió el alcance y contenido de las demidas de reparación, que los impulsores de accountability pleno tendrían que conformarse con una cuota de verdad, las reparaciones correspondientes, y justicia "en la medida de lo posible", ${ }^{19}$ medida finalmente tasada, por administración tras administración, en un nivel mínimo. La verdad revelada por la Comisión Rettig, si bien valiosa, fue relativizada por las instancias más comprometidas en la represión; así tampoco reconoció en forma individualizada a sobrevivientes, sino solamente a víctimas ausentes. La mayoría de las reparaciones económicas iniciales, por ser asociadas con la misma lista de víctimas individualizadas de Rettig, compartían su carácter parcial. ${ }^{20}$ Los sobrevivientes de represión directa, a pesar de ser mucho más numerosos que sus compañeros ausentes o asesinados, fueron efectivamente invisibilizados.

La impunidad jurídica se preservó e incluso se endureció, ya que los tribunales estuvieron poblados a todo nivel con jueces mayoritariamente nombrados durante la dictadura. Estos se mostraron predeciblemente renuentes a revocar sus habituales

19 Una frase empleada por Aylwin para describir su política en materia de justicia, que luego pasó a ser emblemática de su política en materia de justicia de transición en general.

20 Si bien cabe señalar que algunas medidas, tales como el PRAIS, la Oficina de Retornados y el Programa de Exonerados Políticos tuvieron un alcance más amplio.Ver tabla 1. 
prácticas de defensa casi cerrada de impunidad y amnistía, ya que un cambio habría implicado de algún modo un reconocimiento público del notable abandono histórico por parte de la judicatura de sus deberes de defensa de la integridad física de las personas detenidas y de fiscalización horizontal de los otros poderes del Estado. Durante los 1970 y 1980 las cortes en general, y la Corte Suprema en particular, jamás habían objetados la ruptura golpista, el uso de cortes marciales, las leyes secretas, el invento de una nueva constitución ni ningún otro aspecto de la edificación acumulativa de un régimen autoritario legalista y altamente institucionalizado. A diferencia del poder legislativo, el poder judicial, luego de una depuración inicial, nunca fue suspendido en sus funciones ni mayoritariamente intervenido por los militares. Simplemente no hubo necesidad de hacerlo, al margen de algunos pocos fallos valientes, pero fácilmente revocables, realizados por uno que otro juez consciente. Después de todo, se trataba de la misma Corte Suprema que había acogido con satisfacción en 1973 el golpe de Estado, y poco tiempo después, renunció voluntariamente a su poder de supervisión sobre el sistema de justicia militar. A continuación, se había abstenido de facto de hacer efectivo el habeas corpus, o 'recurso de amparo', a favor de los miles de detenidos desaparecidos o presos políticos cuyos casos le fueron presentados por abogados de laVicaría y otras organizaciones de defensa de los DD.HH. ${ }^{21}$

Por tanto, no estaba nada claro ni cómo ni de dónde surgirían las brisas frescas que serían precisas para traer un nuevo aire en lo que concernía a justicia formal. Los abogados privados que representaban casos de DD.HH. seguían alegando para tratar de mantener vivas las causas iniciadas con denuncias de presunta desgracia en los 1970 y 1980, pero la mayoría de éstas aún se encontraban radicadas en el sistema de justicia militar. Allí corrían el permanente peligro de ser archivadas ('sobreseídas'), ya sea de modo temporal o permanente, por la prematura invocación del DL de amnistía o por cualquier otro pretexto que los fiscales y jueces militares pudieron inventar. El pronóstico era bastante pesimista, y Pinochet seguía al mando del Ejército, insistiendo, primero, que sus hombres no habían hecho nada de qué arrepentirse ${ }^{22}$; y, segundo, que ni ellos ni ninguna otra institución de la época contaba con antecedente alguno que pudiera esclarecer el destino final de más de un millar de conciudadanos aún desaparecidos. Figuras de la derecha civil y en el mundo castrense aún insistían, de

21 Se estima que, de más de 10.000 recursos de amparo presentados entre 1973 y 1990 por crímenes de represión, no más de media docena fueron acogidos y ninguno cumplido.

22 Llegando incluso a insinuar, en un discurso nada atípico, que "son ellos [las víctimas] los que deberían pedir perdón, por todos los desmanes que causaron antes del 11 de septiembre [golpe de Estado]". 
hecho, que a pesar de las sobrias y documentadas conclusiones del Informe Rettig, los detenidos-desaparecidos ni siquiera existirían. Se trataría más bien, decían ellos, de una calumnia levantada para enlodar la imagen de las patrióticas fuerzas armadas. Los 'supuestos' desaparecidos -término empleado todavía, casi una década después de Rettig, por representantes militares en una instancia de alto diálogo con el gobiernohabrían muerto en enfrentamientos internos; habrían huido en forma clandestina y cobarde del país para disfrutar de la buena vida en Argentina, o Europa, o Cuba; o simplemente serían un invento malicioso de los detractores del General y su obra.

Ni verdad ni justicia, entonces, transitaron por un camino fácil en los primeros años después del retorno a la democracia electoral. Los familiares que habían albergado esperanzas de ver el retorno de sus seres queridos, o por lo menos la noticia certera de sus defunciones y la devolución de sus restos, fueron quizás los más cruelmente decepcionados. La promesa de la inauguración de Aylwin, cuando invitó a integrantes de la Agrupación de Familiares de Detenidos Desaparecidos a bailar su emotiva 'cueca sola' en el Estadio Nacional, ${ }^{23}$ parecía ya un sueño lejano para muchos. Dos principales agrupaciones, la ya descrita AFDD y la más numerosa, pero entonces menos conocida, Agrupación de Familiares de Ejecutados Políticos (AFEP), seguían agitando y abogando pero su poder terminó siendo más negativo que positivo. Retuvieron suficiente peso moral con algunos diputados de la Concertación como para bloquear o modificar iniciativas legislativas que no les gustaron, ${ }^{24}$ pero no tuvieron suficiente peso ni quizás destreza política como para lograr hacer prosperar sus anhelos más propositivos. En cuanto a los partidos políticos tradicionales, solamente el Partido Comunista, que se había restado del pacto y coalición Concertacionista y constituía por tanto una fuerza extra-parlamentaria, decidió enarbolar la causa de justicia por los crímenes del pasado. Pero esa misma asociación con la causa comunista marginaba aun más las reivindicaciones de la comunidad de DD.HH., en un país en que 17 años de propaganda anti-marxista sin duda habían surtido efecto. ${ }^{25}$

23 Otrora campo de concentración cargado, por tanto, de simbolismo relacionado con los DD.HH.

24 Como las así llamadas 'Leyes Cumplido', un proyecto de ley propuesto por el ministro de Justicia que pretendía realizar una serie de modificaciones en las leyes anti-terroristas y similares; o 'acuerdo marco' sugerido en las mismas fechas para rebajar penas a presos políticos a cambio de no enjuiciar a ex agentes del Estado. A juicio de las agrupaciones, las iniciativas habrían reforzado la impunidad que el DL de amnistía ya insinuaba.

25 Y gracias también, sin duda, a las contradicciones del mismo PC chileno, históricamente férreo defensor del comunismo soviético. En 2011, autoridades del partido enviaron sus condolencias oficiales a Corea del Norte con ocasión de la muerte del dictador Kim Jong-Il; y el PC es regularmente denostado por la derecha chilena por su falta de disposición a expresar críticas al régimen cubano o el venezolano en materia de DD.HH. 
Tabla 1

Principales medidas (simbólicas y/o económicas) de reparación por período presidencial, ^ 1990-2013

\begin{tabular}{|c|c|c|}
\hline PRESIDENTE & MEDIDA & $\begin{array}{c}\text { OBJETIVOS, IMPLEMENTACIÓN y } \\
\text { RESULTADOS }\end{array}$ \\
\hline \multirow{5}{*}{$\begin{array}{l}\text { Patricio Aylwin } \\
(11 \text { de marzo } \\
\text { de } 1990-10 \text { de } \\
\text { marzo de } 1994)\end{array}$} & $\begin{array}{l}\text { a) Oficina Nacional del } \\
\text { Retorno } \\
\text { Ley } 18.994,20 / 08 / 90\end{array}$ & $\begin{array}{l}\text { Promover y acompañar (re)inserción } \\
\text { de quienes deseaban retornar del exilio. } \\
\text { Fecha límite de retorno bajo este } \\
\text { esquema fijada en } 31 \text { de diciembre de } \\
\text { 1993, por Ley } 19.248,30 / 09 / 93 \text {. }\end{array}$ \\
\hline & $\begin{array}{c}\text { b) Programa de } \\
\text { Reparación y Atención } \\
\text { Integral en Salud, PRAIS: } \\
\text { Iniciado 1991, establecido } \\
\text { formalmente por } \\
\text { Resolución Exenta } 729, \\
16 / 12 / 92 .\end{array}$ & $\begin{array}{l}\text { Acceso al sistema de salud pública } \\
\text { y atención psicológica especializada } \\
\text { para personas directa e indirectamente } \\
\text { afectadas por violaciones (familiares, } \\
\text { sobrevivientes y sus parientes más } \\
\text { cercanos, defensores de DD.HH. } \\
\text { que habían trabajado en atención y } \\
\text { acompañamiento a víctimas). }\end{array}$ \\
\hline & $\begin{array}{l}\text { c) Reparaciones } \\
\text { económicas para familiares } \\
\text { de 'víctimas Rettig'. } \\
\text { Ley } 19.123,08 / 02 / 92\end{array}$ & $\begin{array}{c}\text { Pensiones, acceso PRAIS, becas } \\
\text { educacionales y exención del servicio } \\
\text { militar obligatorio para familiares directos } \\
\text { de personas nombradas en el Informe } \\
\text { Rettig como víctimas de desaparición } \\
\text { forzada o ejecución política. Luego } \\
\text { modificada (ampliada o incrementada) } \\
\text { por leyes } 19.980 \text { (2004) y } 20.405 \text { (2009). }\end{array}$ \\
\hline & $\begin{array}{l}\text { d) Programa de } \\
\text { exonerados políticos. } \\
\text { Ley } 19.234,12 / 08 / 93\end{array}$ & $\begin{array}{c}\text { Reponer años de cotización y otras } \\
\text { protecciones sociales, para personas } \\
\text { despedidas del trabajo por motivos políticos. }\end{array}$ \\
\hline & $\begin{array}{l}\text { e) Memorial del Detenido } \\
\text { Desaparecido y del } \\
\text { Ejecutado Político. }\end{array}$ & $\begin{array}{l}\text { En cumplimiento a recomendaciones } \\
\text { Rettig, se construyó, en 1994, un muro } \\
\text { en el Cementerio General con los } \\
\text { nombres de víctimas calificadas y espacios } \\
\text { para el entierro de restos recuperados. }\end{array}$ \\
\hline
\end{tabular}




\begin{tabular}{|c|c|c|}
\hline PRESIDENTE & MEDIDA & $\begin{array}{l}\text { OBJETIVOS, IMPLEMENTACIÓN y } \\
\text { RESULTADOS }\end{array}$ \\
\hline \multirow{5}{*}{$\begin{array}{l}\text { Eduardo Frei } \\
(11 \text { de marzo } \\
\text { de } 1994-10 \text { de } \\
\text { marzo de } 2000)\end{array}$} & $\begin{array}{l}\text { a) Pensiones de gracia para } \\
\text { campesinos 'exonerados } \\
\text { de tierra' (equivalentes de } \\
\text { los exonerados políticos). }\end{array}$ & $\begin{array}{c}\text { Entre } 1995 \text { y } 1996 \text { se otorgaron } \\
\text { pensiones vitalicias, equivalentes a las } \\
\text { de exonerados políticos, a campesinos } \\
\text { expulsados por la dictadura de } \\
\text { asentamientos de la reforma agraria } \\
\text { iniciados en las décadas } 60-70 .\end{array}$ \\
\hline & $\begin{array}{l}\text { b) Expropiación de Villa } \\
\text { Grimaldi: Estado accedió } \\
\text { a petición de adquirir el } \\
\text { terreno de un ex centro } \\
\text { clandestino. }\end{array}$ & $\begin{array}{l}\text { Obras de financiación pública crearon } \\
\text { el 'Parque por la Paz Villa Grimaldi', } \\
\text { inaugurado en marzo } 1997 \text { y } \\
\text { administrado por una Corporación de } \\
\text { sobrevivientes y amigos, con algo de } \\
\text { fondos estatales. }\end{array}$ \\
\hline & $\begin{array}{l}\text { c) Restitución de bienes } \\
\text { confiscados } \\
\text { Ley } 19.568,23 / 7 / 98\end{array}$ & $\begin{array}{c}\text { Dispone la restitución de bienes confiscados } \\
\text { por el Estado durante la dictadura, y/u } \\
\text { otorga indemnización a los afectados. }\end{array}$ \\
\hline & $\begin{array}{l}\text { d) Ley complementaria de } \\
\text { Exonerados } \\
\text { Ley } 19.582,31 / 8 / 98\end{array}$ & $\begin{array}{c}\text { Extiende calidad de exonerados políticos } \\
\text { (Ley 19.234), a ex funcionarios del } \\
\text { Congreso, el Poder Judicial y las FFAA } \\
\text { despedidos ante y pos-golpe. Amplía plazo } \\
\text { de postulación, hasta septiembre } 1999 .\end{array}$ \\
\hline & $\begin{array}{l}\text { e) Derogación del día } \\
11 \text { de septiembre como } \\
\quad \text { feriado } \\
\text { Ley } 19.588,11 / 11 / 98 \text {. }\end{array}$ & $\begin{array}{l}\text { Sustituyó el feriado por el "Día de } \\
\text { la Unidad Nacional", lo cual nunca } \\
\text { prosperó. Este nuevo feriado fue } \\
\text { suprimido por la Ley } 19.793 \text { del } 6 \\
\text { de marzo del 2002, solo alcanzando a } \\
\text { celebrarse } 3 \text { feriados del día de la Unidad } \\
\text { Nacional (en 1999, } 2000 \text { y 2001). }\end{array}$ \\
\hline \multirow[t]{2}{*}{$\begin{array}{l}\text { Ricardo Lagos } \\
(11 \text { de marzo } \\
\text { de } 2000-10 \text { de } \\
\text { marzo de } 2006)\end{array}$} & $\begin{array}{l}\text { a) Leyes de reparación } \\
\text { económica y simbólica: } \\
\text { Ley } 19.740,30 / 6 / 01 \\
\text { Ley } 19.881,27 / 6 / 03 \\
\text { Ley } 19.962,25 / 8 / 04\end{array}$ & $\begin{array}{l}\text { Ley } 19.740 \text { redujo deudas bancarias para } \\
\text { retornados del exilio. } \\
\text { Ley } 19.881 \text { amplió el plazo de } \\
\text { postulación para exonerados políticos. } \\
\text { Ley } 19.962 \text { borró los antecedentes penales } \\
\text { de algunas personas condenadas por } \\
\text { 'crímenes contra la seguridad del Estado' } \\
\text { durante la dictadura. Se excluyeron } \\
\text { crímenes de violencia contra la persona, y } \\
\text { ofensas de tenencia de armas cometidas por } \\
\text { quienes ya tenían antecedentes penales. }\end{array}$ \\
\hline & $\begin{array}{l}\text { b) Medida de garantia de } \\
\text { no-repeticion } \\
\text { Proyecto ley } 20.405 \\
\text { enviado el } 15 / 06 / 05\end{array}$ & $\begin{array}{l}\text { La Ley } 20.405 \text { llevaría eventualmente } \\
\text { a la creación del Instituto Nacional } \\
\text { de DDHH, si bien la oposición de la } \\
\text { derecha política modificó su contenido } \\
\text { y retrasó su aprobación hasta } 2009, \text { y su } \\
\text { activación hasta } 2010 .\end{array}$ \\
\hline
\end{tabular}




\begin{tabular}{|c|c|c|}
\hline PRESIDENTE & MEDIDA & $\begin{array}{l}\text { OBJETIVOS, IMPLEMENTACIÓN y } \\
\text { RESULTADOS }\end{array}$ \\
\hline $\begin{array}{l}\text { Ricardo Lagos } \\
\text { (continua de } \\
\text { página anterior) }\end{array}$ & $\begin{array}{l}\text { c) Leyes relacionadas con } \\
\text { la Comisión Valech } \\
\text { Ley } 19.980,9 / 11 / 04 \\
\text { Ley } 19.992,24 / 12 / 04\end{array}$ & $\begin{array}{l}\text { Ley } 19.980 \text { modificó la ley } 19.123, \\
\text { ampliando las categorías de titulares y/o } \\
\text { incrementando los montos de pensiones } \\
\text { y bonos para familiares de víctimas } \\
\text { ejecutadas y detenidas desaparecidas. } \\
\text { Eliminó discriminación anterior contra } \\
\text { parejas no casadas e hijos nacidos fuera } \\
\text { del matrimonio. } \\
\text { Ley No } 19.992 \text { estableció derecho a } \\
\text { pensión de reparación, acceso PRAIS, y } \\
\text { becas educacionales a las personas que } \\
\text { fueron calificadas por la Comisión Valech } \\
\text { como sobrevivientes de prisión política y } \\
\text { tortura. Estableció incompatibilidad con } \\
\text { derechos de exonerados políticos, obligando } \\
\text { a sobrevivientes reconocidos en ambas } \\
\text { categorías a optar por uno u otro programa. }\end{array}$ \\
\hline $\begin{array}{c}\text { Michelle } \\
\text { Bachelet } \\
(11 \text { de marzo } \\
\text { de } 2006-10 \text { de } \\
\text { marzo de } 2010)\end{array}$ & $\begin{array}{l}\text { a) Inauguración de sitios } \\
\text { de memoria (2006-2010) }\end{array}$ & $\begin{array}{l}\text { Bachelet aceptó inaugurar una serie de } \\
\text { memoriales o sitios recuperados, todos } \\
\text { proyectos de sociedad civil con algún } \\
\text { aporte desde fondos públicos: } \\
\text { 29/3/06 monumento “Un Lugar para la } \\
\text { Memoria”, caso 'degollados' (en honor } \\
\text { a Santiago Nattino, Manuel Guerrero y } \\
\text { José Manuel Parada). } \\
\text { 8/8/07, traspaso en comodato del } \\
\text { ex centro clandestino 'Londres 38' a } \\
\text { agrupaciones DDHH. } \\
\text { 25/5/08 memorial “Paine, un lugar para } \\
\text { memoria”, por } 70 \text { dirigentes campesinos } \\
\text { desaparecidos. } \\
\text { El 9/11/08 se inauguró un monumento } \\
\text { privado a Jaime Guzmán. Hubo polémica } \\
\text { por la invitación, finalmente declinada, } \\
\text { extendida a la presidenta para asistir a } \\
\text { la inauguración a quien había sido el } \\
\text { principal asesor civil de Pinochet. } \\
\text { 3/09/09 inicio de obras en la casa ‘José } \\
\text { Domingo Cañas n } 1367 \text { '. } \\
\text { 11/01/10 inauguración del Museo de la } \\
\text { Memoria y los DDHH. }\end{array}$ \\
\hline
\end{tabular}




\begin{tabular}{|c|c|c|}
\hline PRESIDENTE & MEDIDA & $\begin{array}{l}\text { OBJETIVOS, IMPLEMENTACIÓN y } \\
\text { RESULTADOS }\end{array}$ \\
\hline \multirow[b]{2}{*}{$\begin{array}{c}\text { Michelle } \\
\text { Bachelet } \\
\text { (continua de } \\
\text { página anterior) }\end{array}$} & $\begin{array}{l}\text { b) Declaración del Día } \\
\text { Nacional del Detenido } \\
\text { Desaparecido y del } \\
\text { Ejecutado Político } \\
\\
2006 \text { y } 2010, \\
\text { respectivamente }\end{array}$ & $\begin{array}{l}\text { Declaración del } 30 \text { de agosto como Día } \\
\text { Nacional del Detenido Desaparecido, } \\
\text { Decreto no. } 121,10 \text { de octubre de } 2006 . \\
\text { Declaración del } 30 \text { de octubre como Día } \\
\text { Nacional del Ejecutado Político, Decreto } \\
\text { no. } 119,5 \text { de enero de } 2010 .\end{array}$ \\
\hline & $\begin{array}{l}\text { c) Extensión de medidas } \\
\text { existentes de reparación } \\
\text { económica } \\
\text { Ley } 20.134,22 / 11 / 06 \text {. } \\
\text { Ley } 20.405,10 / 12 / 2009\end{array}$ & $\begin{array}{c}\text { Ley } 20.134, \text { bono económico para } \\
\text { exonerados políticos ya calificados. } \\
\text { Ley 20.405, inicialmente propuesta en 2005, } \\
\text { en la versión finalmente aprobada creó } \\
\text { el Instituto Nacional de DDHH, INDH } \\
\text { (inaugurado en 2010), declaró la reapertura } \\
\text { de las listas Rettig y Valech (realizada en } \\
\text { 2011), estableció la facultad de transferir } \\
\text { becas de estudio a nietos, y amplió el alcance } \\
\text { de exenciones del servicio militar. }\end{array}$ \\
\hline \multirow{5}{*}{$\begin{array}{l}\text { Sebastián Piñera } \\
\text { (11 de marzo } \\
\text { de } 2010 \text { - a la } \\
\text { fecha) }\end{array}$} & $\begin{array}{c}\text { a) Inauguración del } \\
\text { Instituto Nacional de } \\
\text { DDHH, INDH } \\
\text { Constituido en julio } 2010 \\
\text { Operativo desde fines de } \\
2010\end{array}$ & $\begin{array}{c}\text { Tanto esta medida como la de 'Valech } \\
\text { II' fueron aprobadas e iniciadas bajo } \\
\text { administraciones anteriores. }\end{array}$ \\
\hline & $\begin{array}{l}\text { b) Recepción de las listas de } \\
\text { calificación de 'Valech II' } \\
\text { agosto de } 2011\end{array}$ & \\
\hline & $\begin{array}{l}\text { c) Visita al Museo de la } \\
\text { Memoria y los DDHH } \\
\text { abril } 2012\end{array}$ & \\
\hline & $\begin{array}{l}\text { d) Auditoría del Programa } \\
\text { de Exonerados Políticos } \\
\text { 2012-mayo } 2013\end{array}$ & $\begin{array}{l}\text { Para investigar 'irregularidades' en } \\
\text { la aprobación y tramitación de } \\
\text { postulaciones. El informe final de } \\
\text { Contraloría no hizo alusión alguna } \\
\text { a intentos deliberados de fraude: no } \\
\text { obstante, se instruyó un sumario judicial a } \\
\text { petición de parlamentarios de derecha. }\end{array}$ \\
\hline & $\begin{array}{c}\text { e) Propuesta de } \\
\text { subsecretaría de DD.HH }\end{array}$ & $\begin{array}{c}\text { Proyecto de ley bajo discusión } \\
\text { parlamentaria a la fecha de cierre de la } \\
\text { edición (Boletín 8207-07) }\end{array}$ \\
\hline
\end{tabular}

Fuentes: Elaboración propia de investigadores del Observatorio DDHH de la Universidad Diego Portales (Boris Hau y Cath Collins), en base a Loveman y Lira (2005) y a las fuestes de la Ley. 


\section{Fase 2: una cautelosa apertura y un sacudido sísmico: antes y después de Londres 1998}

Con esta escenificación es difícil entender cómo y por qué 1998 resultaría ser un año decisivo, umbral para un vigoroso, si bien aún incompleto, renacimiento de impulsos a verdad, justicia y memoria en Chile. Quizás por la misma condición de inesperadas que tuvieron las irrupciones vividas en esa fecha, existe una tendencia, particularmente desde afuera, de atribuir el giro brusco hacia una mayor cuota de justicia en Chile como producto de intervenciones externas. Se cree, en términos concretos, que las acciones del juez español Baltazar Garzón en pedir la extradición a España de Augusto Pinochet en octubre 1998 fueron la causa de la reapertura de la cuestión de justicia en Chile y del complejo escenario de persecución penal doméstica de crímenes de lesa humanidad que hoy existe. Pero es una interpretación, cuando menos, parcial. 1998 fue un año cargado con mucha significancia y simbolismo desde mucho antes de la inesperada movida de pieza del juez Garzón. Cambios anteriores en la constelación política y jurídica interna en Chile ya habían empezado a dar frutos. En lo particular, en enero de 1998 se habían admitido a tramitación las primeras querellas criminales particulares que acusaran directa y explícitamente a Augusto Pinochet de involucramiento en crímenes contra los DD.HH. En septiembre de 1998, aun antes de que nadie se atreviera a imaginar la emblemática detención en una clínica londinense del octogenario dictador, la Corte Suprema dictó un fallo clave en que aceptó, por primera vez, el argumento legal de que las desapariciones debían ser investigadas a pesar de la ley de amnistía imperante. ${ }^{26}$ Ambas acciones se enmarcan dentro de un año cargado con hechos y aniversarios emblemáticos. En marzo de 1998, al ex dictador le correspondía jubilarse de la FFAA y asumir el escaño vitalicio en el Senado que él mismo se había ingeniado en las letras chicas de la Constitución de 1980. La mera idea de verse obligados a presenciar la solemne recepción de Pinochet como integrante de una legislatura que él mismo había suspendido en su momento, compuesta en parte

26 El fallo de la Corte Suprema en el caso 'Poblete-Cordova' Rol 469-1998, del 9 de septiembre de 1998, fue el primero en que se aceptó dos tesis jurídicas ya planteada con cierta frecuencia desde 1978 por abogados de DDHH: que la ley de amnistía se aplica a personas y no a hechos -por cuanto es aplicada de modo prematuro si no se ha individualizado los responsables de un crimen- y que los Convenios de Ginebra fueron aplicables en Chile en cuanto a inhabilitar la amnistía de crímenes de guerra. Este último, a pesar de la inexistencia real de un conflicto bilateral que reunía las condiciones de un conflicto interno reconocible en el derecho internacional, en virtud de que el régimen dictatorial sí había decretado la existencia de tal estado de cosas como justificación por imponer estados de excepción y de sitio. Ver Observatorio DDHH, 'Principales Hitos Jurisprudenciales en causas DDHH en Chile, 1990-2013'. www.icso.cl/observatorio-derechos-humanos 
por políticos que había consignado al exilio, resultó intolerable para algunos. Entre ellos figuraba un puñado de diputados oficialistas disidentes, quienes entablaron un frustrado intento de acusación constitucional.

La anticipación del mismo amargo momento fue parte de lo que motivó al Partido Comunista, en la persona de su presidenta Gladys Marín, a presentar una querella criminal ya a inicios de 1998 contra Pinochet y otros por la desaparición de altos mandos del PC, entre ellos el marido de Marín. Familiares de víctimas de un notorio episodio represivo llamado 'Caravana de la Muerte' hicieron algo parecido. Ambos grupos querían intentar iniciar sus acciones legales antes que el General adquiriese una capa adicional de protección legal al entrar bajo fuero legislativo por su condición de senador vitalicio. Dicho eso, ninguno de los dos grupos realmente pensaba ver prosperar sus esfuerzos, que consideraban más bien un 'saludo a la bandera' o gesto principalmente simbólico, dadas las proclividades pro-régimen de la judicatura. No obstante, la primera sorpresa del año fue la aceptación de ambas querellas por el juez a quien, por turno, habían sido asignados: el hasta entonces conservador y poco conocido magistrado Juan Guzmán Tapia. Si bien existen diversas razones tanto personales como jurídicas que pueden ayudar a explicar las decisiones puntuales de Guzmán, eran a la vez representativas o expresivas de tendencias más generales, y de data anterior, dentro del sistema de justicia. Una importante reforma judicial, diseñada a principios de los 1990 pero entrando paulatinamente en vigor a partir de 1995 o 1996, había cambiado la cara de la judicatura. Las reformas fueron tanto graduales como técnicas y supuestamente políticamente neutras o consensuadas, y ciertamente no existía en ellas la idea o intención de crear un sistema entusiastamente pro-DD. $\mathrm{HH}$. Pero permitieron, entre otras cosas, el retiro de buena parte de los más férreos adherentes del pinochetismo desde la Corte Suprema y admitieron nuevas tendencias en la forma de 'abogados integrantes', desde fuera de la carrera judicial.

En este contexto de paulatinos cambios de posibilidad y ambiente, sobrevino la dramática detención de Augusto Pinochet en Londres en octubre de 1998, objeto de una petición de extradición a España bajo sospecha de responsabilidad en crímenes cometidos contra ciudadanos españoles -y luego, contra otras víctimas- entre 1973 y 1990. El caso ha sido ampliamente analizado en Brett (2009) por cuanto para efectos del presente texto no se pretenderá un estudio exhaustivo. Sí se puede sostener que el caso y su desenlace -los 503 días de 'arresto domiciliario' del ex dictador en el Reino Unido, los vigoroso esfuerzos diplomáticos para traerlo a casa, y la sensación nacional de ver su proceso de transición, y sistema de justicia, puesto en el balance por la prensa internacional- fue clave en transformar 1998 en un antes y después 
en el tema de justicia doméstica. Según Roberto Garretón, los jueces “perdieron el miedo a hacer justicia” (Observatorio DD.HH., 2013). Según Jorge Correa Sutil, se sentían fuertemente cuestionados por sus colegas internacionales, y según Patricia Politzer, el caso cambió en el país en general la percepción de lo que podría ser posible (Brett, 2009).

De todas maneras, el triunfalismo familiar y militar que rodeó el regreso de Pinochet a Santiago en marzo de 2000 fue matizado o contrarrestado a poco andar. Si bien había logrado burlarse de la justicia española y británica, quedó claro que en el escenario nacional quedaban barreras que sortear. Las ‘querellas Guzmán’ ya sumaban más de 300, con peticiones de procesamiento presentadas por abogados del caso Caravana el mismo día en que aterrizó el avión de la Fuerza Aérea con Pinochet, en silla de ruedas, a bordo.

El gesto de soberbio desdén realizado por el ex dictador a sus perseguidores al abandonar la silla apenas tocado suelo chileno le costó caro. Sumado a la entrevista televisiva que dio unos años más tarde a un Canal de Miami, con ocasión de su cumpleaños, permitía formar una apreciación sobre su estado de salud y lucidez que distaba mucho de la historia oficial utilizada para traerlo a casa. Los jueces chilenos aparentemente se cansaban de tener que respaldar una mentira notoria, y empezaron a dar curso en los tribunales superiores a peticiones de desafuero en cada una de las varias causas que se instruían en su contra. ${ }^{27} \mathrm{Su}$ capital personal y político también se depreciaba paulatinamente: para el mundo castrense, el haberse zafado de la justicia recurriendo a argumentos sobre la salud no cuadraba mucho con la imagen del valiente soldado dispuesto a asumir sus responsabilidades de mando y proteger a sus subalternos. Las causas abiertas en 1998 tenían muchos inculpados, y en la medida en que se empezaba a interrogar y a procesar a ex agentes y militares de todos los rangos, incluyendo a ex conscriptos, el 'muro de silencio' se empezó a derrumbar precisamente entre quienes se sentían traicionados por los altos mandos y por Pinochet. Para la derecha civil, las causas de DD.HH. fueron incómodas pero el caso Riggs fue determinante. El descubrimiento en 2004 de que Pinochet tenía una fortuna personal en cuentas secretas, que no tendría ni origen limpio ni impuestos pagados, fue mucho más incómodo para algunos que cualquier discusión sobre muertes o desapariciones: constituyó, quizás, el inicio de la 'muerte política' del general.

27 Ver Observatorio DDHH, "Historia Judicial de Augusto Pinochet Ugarte", www.icso.cl/ observatorio-derechos-humanos 
Con todo, se llegó al año 2004 con la sensación de un inexorable, si bien lentísimo, avance en justicia doméstica que alcanzó un nuevo punto de inflexión con el fallo Sandoval Rodríguez. ${ }^{28}$ Sería un error atribuir este avance a la voluntad de las autoridades. Las causas en este entonces fueron, sin excepción, producto de querellas privadas realizadas por familiares y sobrevivientes, muchas de ellas reactivando además causas existentes que habían estado adormecidas o sobreseídas dentro de la justicia militar desde tiempos de la misma dictadura. Las y los querellantes, junto con sus abogados, tenían que estar además detrás de cada aspecto de la causa para que ella avanzara, aportando antecedentes, sugiriendo líneas de acción a los magistrados y, en algunos casos, básicamente realizando ellos su propia investigación paralela. Importantes aliados dentro del aparato estatal colaboraron, entre ellos, la Brigada de DD.HH. de la Policía de Investigaciones y el Programa de DD.HH. del Ministerio del Interior, institución heredera de la Comisión Rettig/CNRR. Pero la colaboración fue muchas veces motivada por un compromiso personal de profesionales excepcionales con limitado espacio de maniobra dentro de sus propias instituciones. La letanía de historias de presiones ejercidas desde la oficialidad para desactivar o retrasar los avances en justicia en ese tiempo también da cuenta de que la política oficial de ese tiempo en absoluto fuera de promover activamente la persecución penal de crímenes de represión. Cuando mucho, el deseo prevaleciente parecía ser el de 'manejar' y contener el cauce del rebrote del tema empujado por elementos en la sociedad civil. En ello, sin duda, ayudó el hecho de que a pesar de la bulla mediática generada por la detención de Pinochet, el tema del legado de las violaciones del pasado no fue, como en realidad nunca había sido desde 1990, una preocupación masiva visible ni motivo de movilización más allá del reducido grupo de familiares, abogados y activistas de siempre.

Del mismo modo y en otro ámbito, la 'dimensión verdad' de la justicia de transición también cedió en esta época a presiones desde la sociedad civil para dar nuevas respuestas a problemas de larga data. El primero de estos fue la Mesa de Diálogo, promovida durante la detención de Pinochet en Londres y realizada en 2000 y 2001. Convencidos de que las demandas de justicia podrían ser recanalizadas para constituirse como un problema de verdad, las autoridades lograron convencerse, y convencer a las autoridades castrenses, de que una nueva respuesta a la demanda

28 Fallo de la Corte Suprema, Rol 517-2004, del 17 de noviembre 2004, en que la Corte ratificó una condena dictada contra la cúpula de la DINA por la desaparición de un joven sastre, militante del MIR, aceptando la tesis del 'delito permanente' en que se consideró que la desaparición sigue conformando un delito ejecutándose en la actualidad mientras que la persona secuestrada no sea reintegrada ni sus restos o destino final esclarecidos. (Observatorio Derechos Humanos, 2013a). 
emblemática ‘¿Dónde Están?’ bastaría para apaciguar los ánimos. Conforme a la mentira piadosa de que la culpa principal la tenían individuos indisciplinados y/o la ya disuelta DINA, se preservó la noción de que las fuerzas de orden y seguridad no contaban con antecedentes institucionales.

Más bien éstas, junto con algunas iglesias, 'se ofrecían' para recibir, durante un periodo de algunos meses posteriores a la celebración del acuerdo final de la Mesa, antecedentes desde informantes particulares sobre el paradero final de las personas aún desaparecidas. Ya que investigaciones judiciales realizadas con el protagonismo de los detectives de la Brigada de DD.HH. de la Policía de Investigaciones y de los peritos del Servicio Médico Legal, SML, habían revelado la existencia de por lo menos dos planes sistemáticos de desentierro y reubicación de los restos de personas desaparecidas, asesinadas y enterradas en forma clandestina, se justificó la extensión de la protección del anonimato a los informantes argumentando que en muchos casos su papel se había limitado a estas remociones posteriores, sin tener necesariamente participación directa en, ni conocimiento acabado de, los más graves crímenes iniciales. Agrupaciones de familiares organizados finalmente se restaron de la instancia, desconformes con la continuación de la impunidad que a su juicio la Mesa ofrecía, y la decisión de algunos abogados de DD.HH. de participar provocó desacuerdos y rencillas entre el mundo de los DD.HH. Finalmente, y a pesar de ser celebrada por las autoridades como una histórica instancia de reconocimiento de parte de las fuerzas armadas de la sistematicidad de crímenes de represión, los antecedentes recopilados por la Mesa fueron unas escuetas listas consignando como 'arrojadas al mar' varias decenas de personas aún desaparecidas. Sus resultados fueron además desmentidos al poco andar, cuando investigaciones judiciales paralelas dieron con restos de algunas de las personas mencionadas en un sitio de entierro clandestino en Fuerte Arteaga. Se constató que la justicia ya ofrecía iguales o mejores posibilidades de alcanzar la verdad que la repetición de medidas oficiales que buscaban aislar las dos dimensiones y/o postulaban que la verdad y la justicia eran metas incompatibles entre sí.

Incluso en relación con los antecedentes más confiables aportados por la Mesa, el descubrimiento de nuevos restos produjo 'inflación de demandas' en que los familiares y otros sectores de DD.HH. insistían en la necesidad de saber además quienes fueron los responsables. Se produjo un efecto de dominó, o una cadena de consecuencias no del todo previstas. El traspaso de los antecedentes sobre nuevos restos a la justicia, con la intención de incitar no necesariamente la persecución penal sino labores administrativas de recuperación e identificación, llevó a la designación de nuevos magistrados y ministros especiales. Estos terminaron investigando no solamente estas 
causas sino todas las 'causas DD.HH.' existentes a nivel del país, tanto los expedientes históricos como los abiertos a consecuencia de nuevas querellas pos-1998. La 'caja de Pandora' de la persecución penal no pudo ser sellada nuevamente una vez abierta. Además, las y los sobrevivientes de prisión política y tortura empezaron a constituirse como un sujeto colectivo organizado reivindicando sus propios derechos a verdad, justicia y reparaciones.

Durante muchos años el país en general, las autoridades, y parte del propio sector de DD.HH., había concentrado su atención casi exclusivamente en las 'víctimas ausentes' - desaparecidas y/o asesinadas-, dejando que sus compañeros en las celdas y campos de concentración figuraran, cuando más, como testigos de crímenes cometidos contra otros. A modo de ejemplo, el poder judicial ni siquiera incluía a crímenes cometidos contra sobrevivientes en su definición de 'causas DD.HH.' sino hasta 2011. Pero los sobrevivientes, quienes se habían organizado en función a las querellas nuevas, el arresto de Pinochet en Londres, y el aniversario 25 del golpe de Estado en 1998, se negaron a quedar en las sombras. Surgían y/o se visibilizaron esfuerzos para recuperar sitios clandestinos de tortura, y producciones culturales y artísticas en torno a la experiencia específica de la prisión política y el exilio. Se formaron decenas de nuevas agrupaciones y comandos de ex presas y presos políticos a lo largo del país. Algunos de ellos, asesorados por la histórica organización de DD.HH. CODEPU, lanzaron las primeras querellas en grupo por la tortura de la cual habían sido objeto.

Nuevamente, las demandas de justicia fueron retocadas como requerimientos de mayores cuotas de verdad. Presión desde las organizaciones para un reconocimiento específico e individualizado al crimen de la tortura y sus efectos nefastos fueron parcialmente recogidas por el entonces presidente Ricardo Lagos en su discurso y manifiesto 'No Hay Mañana Sin Ayer', pronunciado en 2003. Se anunciaron medidas que podrían ser interpretadas como una mezcla de iniciativas de verdad y de garantías de no repetición, entre ellos, una centralización y sistematización de los archivos de la Comisión Rettig y la formación de una institucionalidad nacional para velar por la promoción y garantía de derechos fundamentales en nuevas temáticas. Ambas iniciativas tuvieron que esperar hasta la próxima presidencia, la de Michelle Bachelet (2006-2010) para llegar a fruición. Pero el anuncio de una nueva Comisión de la Verdad fue activado en un plano más inmediato, en la forma de la Comisión Valech (2003-2004).

La Comisión fue en ciertos aspectos modelada en su antecesor, la Comisión Rettig, que si bien había documentado la práctica sistemática de la tortura se abstuvo de 
individualizar a sus sobrevivientes. Aquella opción no deja de ser curiosa dado que, primero, los mismos venían siendo reconocidos y atendidos por diversas instancias de reparación tales como el Programa de Exonerados Políticos y el programa de salud PRAIS, y, segundo, que a diferencia de las víctimas de muerte o desaparición, los y las sobrevivientes de tortura y privación ilegal de libertad se encontraban en su mayoría aún presentes y, en algunos casos, más que dispuestos a relatar sus experiencias e identificar a sus victimarios. No obstante, el afán de dejar a la verdad despojada de posibles consecuencias legales fue incluso más manifiesto en Valech que en Rettig: el mandato de la Comisión Valech incorporaba explícitamente una ley de secreto que embargó durante 50 años el uso o difusión de los testimonios incluso por el poder judicial.Valech sería, entonces, una instancia con repercusiones exclusivamente en verdad y reparaciones, una que además subordinaba la tortura a la prisión política, acreditando la calidad de sobreviviente en base a este último. Aquello excluía a casos de personas victimizadas en sus propios hogares, durante allanamientos masivos, y luego de detenciones masivas realizadas durante manifestaciones callejeras. Además, y nuevamente en contradistinción con Rettig -que documentó 'violencia política' de cualquier origen-, Valech se limitó a calificar casos donde la responsabilidad directa de agentes del Estado pudo ser fehacientemente constatada.

Incluso con estas múltiples limitaciones, la primera vuelta de Valech dio cuenta de cerca de 28.000 casos de personas encarceladas y torturadas por motivos de represión política, agregando en un apéndice en 2005 más de mil casos adicionales. Del total de por sobre 29.000 personas, más de mil fueron menores, entre ellos, una cantidad considerable de niños menores de 12 años. El impacto de Valech, incluso con las limitaciones comentadas, fue innegable. La práctica de la tortura, en todos sus cruentos detalles, explotó el mito consolador de que las violaciones habían sido unos 'excesos de guerra', concentradas mayoritariamente en los primeros, más violentos, años después del golpe y/o contra opositores armados que según la lógica bélica podrían considerarse 'blancos legítimos'. Niños, ancianos, mujeres, e incluso nonatos ahora figuraban entre las personas que la dictadura había estimado 'necesario' o conveniente ultrajar, deshumanizar y sujetar a los peores tratos imaginables en tiempos en que su dominio absoluto sobre el país y la vida pública ya fue incuestionable. La revulsión fue generalizada, las vociferantes justificaciones del mundo castrense y de la derecha política se hicieron más escasas, y más personas declararon su aceptación y reconocimiento de que el Informe Valech fue tanto verídico como lapidario. ${ }^{29}$ Se extendieron medidas

29 Sobre la evolución de la opinión pública respecto a este y otros temas relacionados, en la población general y entre los votantes de la derecha en particular, ver Huneeus (2003); y Huneeus e Ibarra (2013). 
de reparación 'sobria y austera', en las palabras de Lagos, a las personas reconocidas porValech. No obstante, el descontento sobre la ausencia de justicia por este segundo círculo concéntrico de violaciones graves fue, en balance, acentuado por la existencia de un reconocimiento en el ámbito de la verdad combinado con un continuo silencio oficial sobre la necesidad y posibilidad de justicia.

Tabla 2

Medidas oficiales en recuperación de la verdad en Chile desde 1990

\begin{tabular}{|c|c|c|c|c|}
\hline & $\begin{array}{c}\text { Rettig y CNRR } \\
1991 ; 1996\end{array}$ & $\begin{array}{c}\text { Mesa de Diálogo } \\
\text { 2000/01 }\end{array}$ & $\begin{array}{l}\text { Valech I } \\
2004 / 05\end{array}$ & $\begin{array}{l}\text { Valech II } \\
2011\end{array}$ \\
\hline Título oficial & $\begin{array}{c}\text { Rettig: } \\
\text { Comisión Nacional } \\
\text { de Verdad y } \\
\text { Reconciliación } \\
\text { CNRR: } \\
\text { Comisión Nacional } \\
\text { de Reparación y } \\
\text { Reconciliación }\end{array}$ & Mesa de Diálogo & $\begin{array}{l}\text { Comisión Nacional } \\
\text { sobre Prisión } \\
\text { Política y Tortura }\end{array}$ & $\begin{array}{c}\text { Comisión } \\
\text { Presidencial Asesora } \\
\text { para la Calificación } \\
\text { de Detenidos } \\
\text { Desaparecidos, } \\
\text { Ejecutados Políticos } \\
\text { y Víctimas de } \\
\text { Prisión Política y } \\
\text { Tortura }\end{array}$ \\
\hline Mandato & $\begin{array}{l}\text { Víctimas de muerte } \\
\text { o desaparición } \\
\text { producto de } \\
\text { violencia política } \\
\text { cometida por } \\
\text { agentes estatales y } \\
\text { no estatales }\end{array}$ & $\begin{array}{l}\text { Recibir y canalizar } \\
\text { información } \\
\text { sobre el destino } \\
\text { final y paradero } \\
\text { de personas aún } \\
\text { desaparecidas }\end{array}$ & $\begin{array}{l}\text { Sobrevivientes de } \\
\text { prisión política y } \\
\text { tortura cometida } \\
\text { por agentes estatales }\end{array}$ & $\begin{array}{l}\text { Sobrevivientes de } \\
\text { prisión política y } \\
\text { tortura por agentes } \\
\text { estatales } \\
\text { y } \\
\text { Víctimas de muerte } \\
\text { o desaparición } \\
\text { producto de } \\
\text { violencia política } \\
\text { cometida por } \\
\text { agentes estatales y } \\
\text { no estatales }\end{array}$ \\
\hline $\begin{array}{l}\text { Informe } \\
\text { final oficial } \\
\text { publicado }\end{array}$ & Sí & $\begin{array}{c}\text { No (listado de } \\
\text { nombres y destinos } \\
\text { solamente) }\end{array}$ & Sí & $\begin{array}{c}\text { No (listado } \\
\text { de nombres y } \\
\text { análisis estadístico } \\
\text { solamente) }\end{array}$ \\
\hline $\begin{array}{c}\text { ¿Antecedentes } \\
\text { traspasados a } \\
\text { la justicia? }\end{array}$ & Sí & $\begin{array}{l}\text { Sí (nombres y } \\
\text { destinos) }\end{array}$ & $\begin{array}{l}\text { No (prohibido por } \\
\text { ley de secreto) }\end{array}$ & $\begin{array}{l}\text { No (prohibido por } \\
\text { ley de secreto) }\end{array}$ \\
\hline $\begin{array}{l}\text { ¿Nombra } \\
\text { víctimas? }\end{array}$ & Sí (de DD y EP) & Sí & Sí & Sí \\
\hline $\begin{array}{c}\text { ¿Nombra } \\
\text { victimarios? }\end{array}$ & No & No & No & No \\
\hline $\begin{array}{l}\text { Ubicación de } \\
\text { archivos }\end{array}$ & $\begin{array}{c}\text { Museo de la } \\
\text { Memoria y los } \\
\text { DDHH y Programa } \\
\text { de DDHH del } \\
\text { Ministerio del } \\
\text { Interior }\end{array}$ & Se desconoce & $\begin{array}{c}\text { Bodega sellada } \\
\text { del Museo de la } \\
\text { Memoria y los } \\
\text { DDHH (Custodia } \\
\text { legal corresponde al } \\
\text { INDH) }\end{array}$ & $\begin{array}{c}\text { Bodega sellada } \\
\text { del Museo de la } \\
\text { Memoria y los } \\
\text { DDHH (Custodia } \\
\text { legal corresponde al } \\
\text { INDH) }\end{array}$ \\
\hline
\end{tabular}

Fuente: Elaboración personal desde datos oficiales 
Mientras tanto, los sitios reclamados transformaron paulatinamente el paisaje nacional, aportando discretas pero acumulativas señales de las huellas de la represión. La instalación de memoriales y placas en sitios no directamente asociados con detención clandestina constituyeron recordatorios potencialmente más visibles aun, en la medida en que se podía resistir la tendencia de autorizarlos principal o exclusivamente en cementerios y otros lugares fuera del recorrido cívico principal. La derecha reconocía implícitamente la potencia de la guerra de los símbolos con sus propias intervenciones, entre ellas la remodelación de la tumba de Jaime Guzmán, y la instalación de un ostentoso monumento privado al máximo símbolo de colaboración civil con el régimen dictatorial en el corazón del barrio acomodado de Santiago. La justicia aportó su parte, y muchos sectores ligados a los DD.HH. recuerdan como la máxima expresión de los nuevos aires que se respiraban la detención y traslado físico, esposado y escoltado, de Manuel Contreras a los tribunales de Santiago para ser notificado en 2004 de su primera condena carcelaria de la nueva época, en el caso Sandoval. A fines de 2006, se vivió una nueva irrupción del pinochetismo no-arrepentido alrededor de la muerte y funeral del ex dictador, pero no se le concedieron honores de Estado y las reacciones desde la derecha oficialista fueron notablemente amortecidas. Se dejaba entrever cierta conciencia de una batalla perdida en cuanto a no seguir defendiendo abiertamente lo más indefendible.

La concentración de los juicios y condenas en los emblemáticos personajes de la DINA permitían seguir hasta cierto punto el doble juego de atribuir responsabilidades a sectores ajenos a las instituciones actuales y/o a personas ya fisicamente ausentes, tales como el mismo Pinochet. Desde el mando castrense se seguía resistiendo más o menos vigorosamente el así-llamado 'desfile de militares' por los tribunales, pero ello tuvo a la vez un efecto perverso de 'abrir el juego' hacia los colaboradores civiles, ya que el mismo ejército empezaba a fomentar referencias a la 'dictadura cívico-militar', diluyendo o repartiendo los costos políticos de la rendición de cuentas hacia los beneficiarios aún poderosos del régimen del que algunos ahora querían distanciarse. No obstante, la práctica arraigada de blindar a oficiales por sobre sus subalternos, o de dejar indefensos a los rangos más bajos de agentes civiles, permitieron a los detectives y abogados utilizar rencores internos en las filas de los ex agentes para avanzar en el esclarecimiento de crímenes y la atribución de responsabilidades. Se vivieron unos cuantos reveses para cada victoria, evidenciado en la precariedad de las mayorías judiciales para la aceptación de los principios de inamnistiabilidad e imprescriptibilidad de crímenes de lesa humanidad; una notable disparidad en la disposición y rigurosidad con la cual los magistrados de primera instancia despachaba las investigaciones bajo su jurisdicción; y finalmente, 
desde mediados de 2007, en la adopción de una fórmula para rebajar o conmutar penas finales en función al tiempo transcurrido entre delito y sanción. Tampoco se legisló sobre el Decreto Ley de Amnistía, que seguía plenamente vigente, bajo el argumento de que el desistimiento en la práctica de aplicarlo a casos de crimen de lesa humanidad hacía innecesario un actuar más robusto en derogarla o anularla. ${ }^{30}$

Tabla 3

Hitos jurisprudenciales en causas DD.HH en Chile, 1998 a 2013*

\begin{tabular}{|c|c|c|c|c|}
\hline Caso o hito & Rol & Tribunal & Fecha & Significado \\
\hline $\begin{array}{l}\text { 1) Querellas contra } \\
\text { Augusto Pinochet, } \\
\text { casos "Caravana de } \\
\text { la Muerte"y "Calle } \\
\text { Conferencia" }\end{array}$ & $\begin{array}{c}2182- \\
1998\end{array}$ & $\begin{array}{l}\text { Juan Guzmán, } \\
\text { Ministro de } \\
\text { Fuero }\end{array}$ & $\begin{array}{c}\text { 12/01/98 } \\
\text { (Conferencia) } \\
\\
28 / 01 / 98 \\
\text { (Caravana) }\end{array}$ & $\begin{array}{l}\text { Las primeras querellas criminales } \\
\text { aceptadas a trámite que señalan } \\
\text { directamente a Augusto Pinochet } \\
\text { como responsable de crímenes } \\
\text { contra los DDHH. Las querellas } \\
\text { aumentaron luego de la detención } \\
\text { de Pinochet en Londres en } \\
\text { octubre 1998. La causa Rol 2182- } \\
1998 \text { agrupaba toda querella } \\
\text { nombrando a Pinochet, y con el } \\
\text { tiempo fue separada en cuadernos } \\
\text { representando distintos incidentes } \\
\text { y víctimas. Luego de la jubilación } \\
\text { del ministro Guzmán y del } \\
\text { fallecimiento de Pinochet en } 2006 \text {, } \\
\text { las causas siguen abiertas contra } \\
\text { otros imputados. }\end{array}$ \\
\hline $\begin{array}{c}\text { 2) Desaparición } \\
\text { de Pedro Poblete } \\
\text { Córdova }\end{array}$ & $\begin{array}{l}469- \\
1998\end{array}$ & Corte Suprema & 09/09/98 & $\begin{array}{l}\text { La Corte Suprema ordenó } \\
\text { reabrir el sumario de una causa } \\
\text { que había sido amnistiada por } \\
\text { la justicia militar. Estableció que } \\
\text { antes de aplicar la amnistía era } \\
\text { necesario agotar la investigación } \\
\text { estableciéndose la identidad de } \\
\text { los criminales. Declaró que el } \\
\text { Decreto Ley No5 de la dictadura } \\
\text { hizo aplicables los Convenios } \\
\text { de Ginebra, obligando al Estado } \\
\text { chileno a sancionar crímenes de } \\
\text { guerra. Insinuó que los Convenios } \\
\text { de Ginebra tienen rango } \\
\text { 'supraconstitucional' }\end{array}$ \\
\hline
\end{tabular}

30 Esta inercia dejaba a Chile además en manifiesto incumplimiento de un fallo adverso de la Corte Interamericana, en el caso Almonacid (op.cit.), y de una promesa explicita posterior de legislar para 'adecuar' la interpretación del código penal con las responsabilidades internacionales de Chile en la materia.Ver, inter alia, Informe Anual de los DDHH de la Universidad Diego Portales, ediciones 2007 y ss., www.derechoshumanos.udp.cl y el fallo de la Corte Interamericana en el caso García Lucero vs. Chile, 2013. 


\begin{tabular}{|c|c|c|c|c|}
\hline Caso o hito & Rol & Tribunal & Fecha & Significado \\
\hline $\begin{array}{l}\text { 3) Primer desafuero } \\
\text { de Augusto Pinochet }\end{array}$ & & $\begin{array}{l}\text { Corte de } \\
\text { Apelaciones de } \\
\text { Santiago }\end{array}$ & 06/03/00 & $\begin{array}{l}\text { El desafuero fue ratificado por } \\
\text { el Pleno de la Corte el } 23 \text { de } \\
\text { mayo de 2000, permitiendo el } \\
\text { procesamiento de Pinochet en el } \\
\text { caso "Caravana de la Muerte". Fue } \\
\text { aprobado con } 13 \text { votos en favor y } \\
9 \text { en contra. }\end{array}$ \\
\hline $\begin{array}{c}\text { 4) Primer } \\
\text { procesamiento de } \\
\text { Augusto Pinochet }\end{array}$ & N/A & $\begin{array}{l}\text { Juan Guzmán, } \\
\text { Ministro de } \\
\text { Fuero }\end{array}$ & $01 / 12 / 00$ & $\begin{array}{l}\text { Primer auto de procesamiento } \\
\text { contra Pinochet, como co-autor } \\
\text { del secuestro y desaparición de } \\
19 \text { personas y del homicidio } \\
\text { de otras } 55 \text {, en el episodio } \\
\text { "Caravana". Luego fue revocado } \\
\text { por la Corte de Apelaciones } \\
\text { por defectos de forma, rechazo } \\
\text { ratificado por la Corte Suprema. }\end{array}$ \\
\hline $\begin{array}{l}\text { 5) Primera designación } \\
\text { de ministros de } \\
\text { dedicación exclusiva y } \\
\text { preferente en causas }\end{array}$ & N/A & Corte Suprema & $20 / 06 / 01$ & $\begin{array}{l}\text { Designación de } 9 \text { ministros } \\
\text { de dedicación exclusiva, y } 51 \\
\text { jueces de dedicación preferente, } \\
\text { para investigar causas DDHH, } \\
\text { incluyendo } 114 \text { casos de } \\
\text { desaparición de personas. Las } \\
\text { designaciones fueron ampliadas en } \\
2002 \text { y } 2004, \text { y en } 2010 \text { se nombró } \\
\text { por primera vez un ministro de } \\
\text { la Corte Suprema para coordina } \\
\text { estos procesos. Los ministros } \\
\text { respectivos ya eran de fuero (rango } \\
\text { de Corte de Apelaciones), si bien } \\
\text { se fue perdiendo la designación de } \\
\text { exclusividad. }\end{array}$ \\
\hline $\begin{array}{l}\text { 6) Desaparición } \\
\text { de Miguel Ángel } \\
\text { Sandoval Rodríguez }\end{array}$ & $\begin{array}{l}517- \\
2004\end{array}$ & Corte Suprema & $17 / 11 / 04$ & $\begin{array}{l}\text { Fallo afirmando que secuestro } \\
\text { calificado tiene la calificación } \\
\text { jurídica internacional de } \\
\text { desaparición forzada, y } \\
\text { rechazando amnistía o } \\
\text { prescripción para delitos } \\
\text { permanentes mientras no se } \\
\text { tenga el cuerpo de la víctima. } \\
\text { Primera condena a Manuel } \\
\text { Contreras por secuestro, llevando } \\
\text { al ex director de la DINA a una } \\
\text { nueva encarcelación luego de } \\
\text { cumplir su corta condena en el } \\
\text { caso Letelier (1995). Se producen } \\
\text { fuertes manifestaciones en contra } \\
\text { de Contreras en las afueras de los } \\
\text { tribunales. }\end{array}$ \\
\hline
\end{tabular}




\begin{tabular}{|c|c|c|c|c|}
\hline Caso o hito & Rol & Tribunal & Fecha & Significado \\
\hline $\begin{array}{l}\text { 7) Muerte de Augusto } \\
\text { Pinochet - } 10 \\
\text { diciembre } 2006\end{array}$ & \multicolumn{4}{|c|}{$\begin{array}{l}\text { Produce el sobreseimiento por muerte de las investigaciones en causas } \\
\text { DDHH y causa de corrupción (caso Riggs) que se seguía en su contra. } \\
\text { Las investigaciones siguen activas en contra de los demás responsables y } \\
\text { eventuales imputados en los mismos crímenes, si bien en julio } 2013 \text { se } \\
\text { sobreseyó la causa Riggs sin procesados de la familia Pinochet. }\end{array}$} \\
\hline $\begin{array}{l}\text { 8) Fallo adverso de la } \\
\text { Corte Interamericana } \\
\text { de DDHH contra } \\
\text { Chile: Caso } \\
\text { Almonacid }\end{array}$ & N/A & $\begin{array}{l}\text { Corte Inter- } \\
\text { Americana de } \\
\text { DDHH }\end{array}$ & $26 / 09 / 06$ & $\begin{array}{l}\text { Denuncia 12.057, recibida por } \\
\text { la Comisión Interamericana el } \\
\text { 15/09/98, ingresada a la Corte } \\
\text { IDH 11/07/05. Alega denegación } \\
\text { de justicia por el Estado de Chile, } \\
\text { en violación de los Arts. } 8 \text { y } 25 \\
\text { de la Convención Americana } \\
\text { de DDHH, suscrita y ratificada } \\
\text { por Chile en 1990, por la } \\
\text { aplicación del DL de amnistía } \\
\text { por un tribunal militar en el caso } \\
\text { de Luis Almonacid Arellano. El } \\
\text { fallo declaró que el DL es una } \\
\text { autoamnistía que "carece de efectos } \\
\text { jurídicos" y no puede seguir } \\
\text { impidiendo la investigación y } \\
\text { castigo de este y otros crímenes de } \\
\text { la misma naturaleza. }\end{array}$ \\
\hline $\begin{array}{l}\text { 9) Asesinatos de Hugo } \\
\text { Vásquez y Mario } \\
\text { Superby }\end{array}$ & $\begin{array}{l}559- \\
2004\end{array}$ & Corte Suprema & $13 / 12 / 06$ & $\begin{array}{l}\text { Por primera vez se acepta la } \\
\text { calificación de crimen de lesa } \\
\text { humanidad en un caso de } \\
\text { ejecución política (todos los } \\
\text { casos anteriores habían sido } \\
\text { por desaparición). También por } \\
\text { primera vez la sala fundamenta } \\
\text { invocando el fallo Almonacid de } \\
\text { la Corte Interamericana (parrs. } \\
96 \text { y 99). }\end{array}$ \\
\hline $\begin{array}{c}\text { 10) Desaparición } \\
\text { de Juan Luis Rivera } \\
\text { Matus }\end{array}$ & $\begin{array}{c}3.808- \\
2006\end{array}$ & Corte Suprema & $30 / 07 / 07$ & $\begin{array}{l}\text { Retroceso: el primero de una } \\
\text { serie de fallos (hasta el } 2012, \\
\text { y nuevamente a partir de } \\
\text { mediados de 2013) que rebajan } \\
\text { las penas finales a través de la } \\
\text { prescripción gradual (Art } 103 \\
\text { del Código Penal). Clasifica la } \\
\text { prescripción gradual como una } \\
\text { atenuante, para fundamentar } \\
\text { su aplicabilidad a pesar de } \\
\text { reconocer la inaplicabilidad de } \\
\text { prescripción plena. }\end{array}$ \\
\hline
\end{tabular}




\begin{tabular}{|c|c|c|c|c|}
\hline Caso o hito & Rol & Tribunal & Fecha & Significado \\
\hline $\begin{array}{c}\text { 11) Desaparición } \\
\text { de Jacqueline Binfa } \\
\text { Contrera }\end{array}$ & $\begin{array}{c}4.329- \\
2008\end{array}$ & Corte Suprema & $22 / 01 / 09$ & $\begin{array}{c}\text { Fuerte revés jurisprudencial, } \\
\text { emitido en época de } \\
\text { verano, con una Sala Penal } \\
\text { con una conformación } \\
\text { temporal particularmente } \\
\text { desfavorable. Atribuye al } \\
\text { derecho internacional rango } \\
\text { infraconstitucional, y desecha la } \\
\text { aplicabilidad de los Convenios } \\
\text { de Ginebra por no reconocer la } \\
\text { existencia a la fecha del delito de } \\
\text { un estado de conmoción interna. }\end{array}$ \\
\hline $\begin{array}{c}\text { 12) Asesinatos de los } \\
\text { hermanos Vergara } \\
\text { Toledo }\end{array}$ & $\begin{array}{c}7.089- \\
2009\end{array}$ & Corte Suprema & $04 / 08 / 10$ & $\begin{array}{l}\text { Desecha la investigación } \\
\text { realizada por la justicia militar } \\
\text { durante la dictadura como un } \\
\text { mero "simulacro de juicio", } \\
\text { denegando la excepción de la } \\
\text { cosa juzgada dado el poco o } \\
\text { nulo avance real que se dio en la } \\
\text { investigación inicial. }\end{array}$ \\
\hline $\begin{array}{l}\text { 13) Desaparición de } \\
\text { Rudy Cárcamo }\end{array}$ & $\begin{array}{l}288- \\
2012\end{array}$ & Corte Suprema & $24 / 05 / 12$ & $\begin{array}{l}\text { Una renovada conformación } \\
\text { de la sala penal declara no } \\
\text { aplicable la prescripción } \\
\text { gradual, por tratarse tanto de } \\
\text { un delito permanente como de } \\
\text { un crimen de lesa humanidad, } \\
\text { ambos imprescriptibles. Así } \\
\text { implícitamente reconoce la } \\
\text { identidad entre prescripción } \\
\text { gradual y prescripción plena. } \\
\text { Primera vez desde } 2007 \text { (caso } \\
\text { Rivera Matus) en que se desiste } \\
\text { de invocar prescripción gradual } \\
\text { en un caso de desaparición } \\
\text { forzada. }\end{array}$ \\
\hline $\begin{array}{l}\text { 14) Homicidio de } \\
\text { Gloria Stockle }\end{array}$ & $\begin{array}{c}2.200- \\
2012\end{array}$ & Corte Suprema & $21 / 09 / 12$ & $\begin{array}{l}\text { A pesar de la aparición del } \\
\text { nombre de la víctima en } \\
\text { Informe Rettig, el fallo parece } \\
\text { no reconocer el caso como un } \\
\text { crimen de lesa humanidad, a } \\
\text { pesar de su fecha de comisión } \\
\text { (en tiempos de dictadura) y } \\
\text { la responsabilidad establecida } \\
\text { (confiesa) de agentes estatales. } \\
\text { Lo penaliza como un crimen } \\
\text { común (homicidio simple) }\end{array}$ \\
\hline
\end{tabular}




\begin{tabular}{|c|c|c|c|c|}
\hline Caso o hito & Rol & Tribunal & Fecha & Significado \\
\hline $\begin{array}{l}\text { 15) Desaparición de } \\
\text { GroberVenegas }\end{array}$ & $\begin{array}{c}3573- \\
2012\end{array}$ & Corte Suprema & $23 / 11 / 12$ & $\begin{array}{l}\text { Primer caso desde } 2004 \text { en que } \\
\text { la Corte desconoció el carácter } \\
\text { permanente de un crimen de } \\
\text { secuestro, al adoptar un plazo de } \\
91 \text { días después de la desaparición } \\
\text { como fecha de consumación del } \\
\text { delito. Se deduce que el crimen } \\
\text { fue considerado punible solo en } \\
\text { razón de su carácter de crimen } \\
\text { de lesa humanidad, y no por su } \\
\text { carácter permanente. La tendencia } \\
\text { fue continuada en el próximo caso } \\
\text { de similares características, el de } \\
\text { desaparición de Cecil Alarcón (Rol } \\
\text { 64-2009 de } 18 \text { de julio de 2013) }\end{array}$ \\
\hline $\begin{array}{l}\text { 16) Resolución del } \\
\text { Pleno de la Corte } \\
\text { Suprema sobre } \\
\text { prescripción de } \\
\text { demandas civiles }\end{array}$ & $\begin{array}{c}10665- \\
2011\end{array}$ & Corte Suprema & $21 / 01 / 13$ & $\begin{array}{l}\text { El Pleno de la Corte Suprema } \\
\text { apoyó la prescripción de } \\
\text { demandas civiles, a pesar de } \\
\text { reconocer la imprescriptibildad } \\
\text { de responsabilidades penales. } \\
\text { Consideró que la fecha a partir } \\
\text { de la cual se contabiliza la } \\
\text { aplicación de la prescripción } \\
\text { en materia civil es la entrega } \\
\text { del Informe Rettig (1991). A } \\
\text { pesar de esta resolución, en su } \\
\text { siguiente fallo en la materia } \\
\text { la Sala Penal de la Corte sí } \\
\text { concedió indemnización }\end{array}$ \\
\hline
\end{tabular}

^ Los fallos nacionales mencionados pueden ser consultados en el sitio web del poder judicial, www.pjud.cl, ingresando el número de Rol citado para cada caso. Mayor detalle sobre cada hito se encuentra en una versión más completa y actualizada de esta tabla, publicada como Observatorio DDHH "Principales hitos Jurisprudenciales en causas DDHH en Chile 1990-2013", www.icso.cl/observatorio-derechos-humanos

Con todo,llegando a mediados de 2012, el saldo ascendía a 268 ex agentes condenados por al menos un crimen relacionado con violaciones a los DD.HH., con 569 más procesados o con una condena en espera de ratificación en apelación. Gracias a las prácticas extendidas de rebaja o conmutación de penas y de la concesión de excarcelaciones tempranas, menos de un tercio de los 268 condenados finales -84 individuos- habían cumplido penas de cárcel, con una docena de éstos ya liberados. Además, $80 \%$ de las penas de cárcel se cumplían en las condiciones benignas de recintos militares, uno de ellos (Punta Peuco) construido especialmente para aquel propósito. La lentitud de estos procesos y de las 1.361 causas aún pendientes también 
constituía un problema tanto para los acusados como para las víctimas y familiares ${ }^{31}$. Muchos de ellos no alcanzaron a ver los resultados de los procesos que habían iniciado más de una década y media antes, en 1998, en plena efervescencia de esperanza y fe en la nueva era de la justicia. Las causas abiertas aún dejaban fuera casi un tercio de las víctimas reconocidas de desaparición o muerte, y casi la totalidad de los sobrevivientes de tortura, de quienes menos de 1\% tenían causas abiertas por los crímenes cometidos en su contra. No obstante, representa un balance inimaginable tan solo una década y media antes, demostrando en definitiva que las transacciones y limitantes imperantes en el momento de transición sí son susceptibles a cambios posteriores en el balance de lo posible.

\section{Conclusiones: Chile desde la 'transición modelo' al lento despertar de la justicia}

Durante la primera presidencia de Michelle Bachelet (2006-2010), se acentuaron avances en la dimensión simbólica de la reparación, con la inauguración presidencial de una serie de monumentos y sitios de memoria, más la reorganización de la unidad de identificación del Servicio Médico Legal y la construcción de un Museo de la Memoria y los DD.HH. Otra instancia más claramente enfocada hacia garantías de no repetición, el Instituto Nacional de Derechos Humanos, INDH, fue finalmente encaminado luego de años de discusión y negociación con la derecha. En el ámbito de la justicia Bachelet fue más cautelosa, al igual que sus predecesores. Nuevamente fueron las agrupaciones de familiares y sobrevivientes, asistidas esta vez por el Programa de DD.HH. y el poder judicial actuando ex oficio, quienes iniciaron o reactivaron causas tanto por personajes 'connotados' -el ex presidente Allende, el poeta Pablo Neruda, el cantante Víctor Jara, y el mismo padre de la presidenta- como por las víctimas 'anónimas' cuyos casos nunca habían sido debidamente investigados. También se anunció una nueva, y supuestamente definitiva, rueda de calificación y reconocimiento en la forma de una 'comisión presidencial calificadora', conocida como Valech II, que agregó casi 10.000 sobrevivientes, y 30 ‘víctimas Rettig’, a las listas oficiales.

A la vez, se seguían librando las batallas simbólicas y polémicas de siempre: la aparición con vida, en noviembre de 2008, una de las personas hasta entonces consignadas en

31 Cifras actualizadas a fines del 2012 sobre los procesos aun en curso fueron recibidas por la autora en diciembre 2013, fecha que no permitía su procesamiento y análisis a tiempo para ser incorporadas a la presente edición. El recinto Cordillera, uno de los dos recintos especiales, fue clausurado a fines de septiembre del 2013, ocasionando el traslado de sus 9 reos a Punta Peuco.Ver, al respecto, boletínes del Observatorio DD.HH, disponibles en la página www.icso.cl/observatorio-derechos-humanos, sección Boletínes y Publicaciones. 
la lista Valech dio pie a una larga contienda con la derecha política que redundó en acusaciones de falsificación o fraude en las listas de exonerados políticos. Era de esperar que la entrada de un gobierno de derecha, bajo la presidencia de Sebastián Piñera (20102014) acentuaría estas batallas y/o desactivaría algunas de las iniciativas ya encaminadas. En los hechos, la nueva administración se limitó a restarle importancia y protagonismo a las instancias ya concedidas. Pero el impacto del cambio fue amortiguado por el mismo hecho de que dichas instancias habían tenido que aprender a operar en los espacios límites de la institucionalidad, nutridas desde la insistencia de la sociedad civil más que por claros liderazgos de alto nivel. Por tanto los avances en materia de justicia de transición resultaron ser relativamente poco susceptibles a cambios en la esfera de la alta política. La justicia seguía su marcha lenta, si bien con ocasionales reveses, y el advenimiento de unas nuevas 'fechas emblemáticas' - el cuadragésimo aniversario del golpe de Estado y el decimoquinto aniversario de las querellas nacionales y el 'caso Pinochet'- ejercían una fuerza social propia fuera del ámbito del control oficial. La justicia de transición, en su segunda fase en Chile, ha resultado así ser a la vez más difusa y más difícil de gestionar para las autoridades políticas que su contraparte inicial, y Chile, a la par del resto de la región, parece estar desde ya embarcado en un irreversible reencuentro con su historia reciente. Un inmediato y potente síntoma de aquel reencuentro fueron las acciones del entonces presidente de derecha, Sebastián Piñera en torno al mismo 'aniversario 40 del 11'. Abandonando de modo repentino una política que parecía buscar hacerle caso omiso a la fecha, terminó haciendo uso del aniversario para rayar una línea dentro de su misma tienda, intentando trazar una brecha entre corrientes en la derecha que reconocen - y están, en alguna medida, dispuestas ya de repudiar - las violaciones cometidas bajo la dictadura, y otras que su propio gobierno llegó a tachar como 'Pinochetistas que no saben vivir en democracia'. Incluso quienes dudaron de la sinceridad de la conversión, o remarcaron el énfasis nada casual en verdad y reparaciones, por sobre justicia, no pudieron sino reconocer el avance que representa en comparación con la negación abierta que aun florecía, hace relativamente poco tiempo, en el corazón de la misma derecha chilena al respecto.

\section{Referencias bibliográficas}

Angell Alan (2006). "The Pinochet Regime: An Accounting", Open Democracy, http:// www.opendemocracy.net/democracy-protest/pinochet regime 4174.jsp.

Angell, Alan (2013). "Prologue”. En Sehnbruch, Kirsten y Peter Siavelis (editores). Chile Under the Concertación. Boulder: Lynne Rienner Press.

Brett, Sebastián (2009). “El Efecto Pinochet. A 10 años de Londres 1998”. Informe seminario internacional. Santiago: Universidad Diego Portales. 
Corte Interamericana de DD.HH., sentencia de 26 de septiembre de 2006, Almonacid y otros vs. Chile.

Corte Suprema de Justicia de Chile, Fallo Rol 517-2004, caso Sandoval Rodríguez

Corporación Nacional de Reparación y Reconciliación, CNRR (1996). Informe sobre la Calificación de Víctimas deViolaciones de Derechos Humanos y de laViolencia Política. Santiago: Edición de la Corporación Nacional de Reparación y Reconciliación.

Huneeus, Carlos (2003). Chile, un país dividido. Santiago: Catalonia.

Huneeus, Carlos (2011). El Régimen de Pinochet Santiago: Editorial Sudamericana.

Huneeus, Carlos y Sebastián Ibarra (2013). "La Memoria del Régimen de Pinochet desde la Opinión Pública”. En Collins, Cath, Alfredo Joignant y Katherine Hite (eds.) La Política de la Memoria en Chile desde Pinochet a Bachelet, Santiago, Editorial UDP, en prensa.

Joignant, Alfredo (2013). "El funeral de Pinochet. Memoria, historia e inmortalidad". En Collins, Cath, Alfredo Joignant y Katherine Hite (eds.) La Política de la Memoria en Chile desde Pinochet a Bachelet, Santiago, Editorial UDP, en prensa.

Loveman, Brian y Elizabeth Lira (2001). Leyes de reconciliación en Chile:Amnistías, indultos y reparaciones 1819-1999. Santiago: LOM/DIBAM, Centro de Investigaciones Diego Barros Arana, Serie Fuentes para la Historia de la República vol. XVII, Universidad Alberto Hurtado.

Loveman, Brian, y Elizabeth Lira (2002). Arquitectura Política y Seguridad Interior del Estado, Chile 1811-1990. Santiago: LOM/DIBAM, Centro de Investigaciones Diego Barros Arana, Serie Fuentes para la Historia de la República, vol. XIX. Universidad Alberto Hurtado.

Loveman, Brian y Elizabeth Lira (2005). Políticas de Reparación: Chile 1990-2004. Santiago: LOM.

Muñoz, Oscar (2007). El Modelo Económico Chileno de la Concertación 1990-2005. Santiago: FLACSO y editorial Catalonia.

Observatorio DD.HH. (2013a). Principales hitos Jurisprudenciales en causas DD.HH. en Chile 1990-2013, Santiago: Universidad Diego Portales. www.icso.cl/observatorioderechos-humanos.

Observatorio DD.HH. (2013b). "Capítulo Verdad, Justicia y Memoria". En anual de DDHH de la Universidad Diego Portales, Santiago: Universidad Diego Portales.

Observatorio DD.HH. (2013c). "Cifras de vìctimas y sobrevivientes de violaciones masivas a los DD.HH. oficialmente reconocidos por el Estado chileno". www.icso.cl/ observatorio-derechos-humanos 
Observatorio DD.HH. (2012). "Medidas de Reparaciòn en Chile desde 1990" y "Tabla leyes y medidas de reparacion en Chile". www.icso.cl/observatorio-derechos-humanos

Observatorio DD.HH. (s/f). "Historia Judicial de Augusto Pinochet Ugarte", www.icso.cl/ observatorio-derechos-humanos.

Primer Informe Anual del Relator Especial de la ONU para la Promoción de la Verdad, la Justicia, las Reparaciones y las Garantías de No-Repetición, agosto de 2012. ONU A/ $\mathrm{HRC} / 21 / 46$.

Resolución 18/7 del Consejo de DDHH de la ONU, que establece el Relator Especial de la ONU para la Promoción de la Verdad, la Justicia, las Reparaciones y las Garantías de No-Repetición, de 29 de septiembre de 2011, adoptada en 13 de octubre de 2011. A/ $\mathrm{HRC} / \mathrm{RES} / 18 / 7$.

Wilde, Alex (1999). "Irruptions of Memory: Expressive Politics in Chile's transition to democracy". Journal of Latin American Studies,Vol. 31 N² 2, pp. 473-500. 
